\title{
HIV reservoirs in vivo and new strategies for possible eradication of HIV from the reservoir sites
}

This article was published in the following Dove Press journal:

HIVIAIDS - Research and Palliative Care

II June 2010

Number of times this article has been viewed

\author{
Nitin K Saksena \\ Bin Wang \\ Li Zhou \\ Maly Soedjono \\ Yung Shwen Ho \\ Viviane Conceicao
}

Retroviral Genetics Division, Center for Virus Research, Westmead Millennium Institute, The University of Sydney, Westmead, NSW, Sydney, Australia
Correspondence: Nitin K Saksena Retroviral Genetics Division, Center for Virus Research, Westmead Millennium Institute, Westmead NSW 2I45, Sydney, Australia

$\mathrm{Tel}+61298459119$

$\mathrm{Fax}+61298459103$

Email nitin_saksena@wmi.usyd.edu.au

\begin{abstract}
Even though the treatment of human immunodeficiency virus (HIV)-infected individuals with highly active antiretroviral therapy (HAART) provides a complete control of plasma viremia to below detectable levels ( $<40$ copies/mL plasma), there is an unequal distribution of all antiretroviral drugs across diverse cellular and anatomic compartments in vivo. The main consequence of this is the acquisition of resistance by HIV to all known classes of currently prescribed antiretroviral drugs and the establishment of HIV reservoirs in vivo. HIV has a distinct advantage of surviving in the host via both pre-and postintegration latency. The postintegration latency is caused by inert and metabolically inactive provirus, which cannot be accessed either by the immune system or the therapeutics. This integrated provirus provides HIV with a safe haven in the host where it is incessantly challenged by its immune selection pressure and also by HAART. Thus, the provirus is one of the strategies for viral concealment in the host and the provirus can be rekindled, through unknown stimuli, to create progeny for productive infection of the host. Thus, the reservoir establishment remains the biggest impediment to HIV eradication from the host. This review provides an overview of HIV reservoir sites and discusses both the virtues and problems associated with therapies/strategies targeting these reservoir sites in vivo.
\end{abstract}

Keywords: HIV, HAART, reservoirs, compartmentalization, elimination strategies for reservoirs, AIDS

\section{Introduction}

Since the discovery of human immunodeficiency virus (HIV) type 1 and the recognition that HIV is the causal agent of acquired immunodeficiency syndrome (AIDS) in 1983, ${ }^{1}$ over 25 million people have died of AIDS. It is estimated that 33 million people are now currently living with the deadly disease. ${ }^{2}$ Among the 33 million infected $92.7 \%$ are adults, $46.4 \%$ are females, and $7.5 \%$ are children. In the year 2007 , the World Health Organization estimated that 2.7 million people were newly infected with HIV and a further 2 million people died of AIDS-related diseases that year. Of the 33 million currently living with AIDS, $68 \%$ of the individuals are living in the sub-Saharan Africa. Following that, South East Asia is the next largest region affected by HIV and accounts for an estimated $12 \%$ of the globally infected population. Individuals with AIDS, who live in North America, Latin America and Eastern Europe to central Asia, account for an estimated $4 \%$ each. It is therefore not surprising that the majority of people living with HIV inhabit the world's poorest regions. This is due to the lack of access to HIV prevention and treatment among the poor and marginalized populations. ${ }^{3}$ This has resulted in the continual dissemination of the virus among marginalized populations. 
The introduction of highly active antiretroviral therapy (HAART) has provided HIV patients with a prolonged life and has led to a considerable decline in co-morbidities and mortality in HIV patients. Even though a significant proportion of HIV-infected individuals receiving antiretroviral treatment can achieve below detectable limits (BDL) of plasma viremia $(<40$ copies $/ \mathrm{mL}),{ }^{4}$ the acquisition of drug resistance by HIV to practically all currently prescribed classes of antiretroviral drugs is the biggest impediment to the clinical management of HIV patients and the successful outcome of antiretroviral therapy.

HIV can continue to replicate at very low levels even during effective HAART. Persistent infection of nonactivated T-lymphocytes (where low levels of viral replication occurs) has been detected in individuals on successful HAART with BDL. ${ }^{5}$ Thus, it is apparent that HAART exerts considerable selection pressure on HIV, which provides partial restoration of the host immune system. In this tussle HIV is a winner, as it is able to conceal itself by establishing reservoir and sanctuary sites, which show disparate and suboptimal drug penetration. As a consequence the suboptimal drug concentrations, that reside in these diverse reservoir sites, encourage the emergence of drug-resistant HIV strains. In addition, HIV is also able to safeguard its survival in the face of HAART and strong host immune selection pressure through proviral integration into the host genome. This provirus being inert to the host immune system is ideal for latent reservoir establishment in vivo. Latent cellular reservoirs may hinder attempts at HIV eradication. Latency is a common feature of all retroviruses and is one of the most important host cell-virus interactions whereby the virus can survive and persist in the face of the immune response and antiviral therapy. Of major concern is the re-emergence and spread of HIV-1 variants from reservoirs after the withdrawal or failure of HAART because the emerging variants are as fit as, or in some cases fitter than the wild type virus.

Although much has been learnt about the mechanisms and sites of HIV persistence and reservoir establishment during drug therapy, ${ }^{6,7}$ the failure to eliminate latent viral reservoirs is a major shortcoming of the current HAART regimens. ${ }^{8}$ New strategies are being developed to flush virus out of these reservoirs, which may provide the complete eradication of HIV in vivo in the future.

The present review is focused on HIV reservoirs and the eradication of HIV from them. It attempts to provide a comprehensive overview of what we have achieved so far in the understanding of HIV reservoirs, strategies to overcome the establishment of and viral elimination from these reservoirs; in addition to approaches and products in the pipeline for eliminating HIV from these reservoir sites.

\section{Definition of a viral reservoir}

A viral reservoir is a cell type or anatomical site, where a replication-competent form of HIV can accumulate and persist stably. The definition of a viral reservoir should have two vital elements for it to be termed "reservoir". To be biologically significant, a reservoir must preserve some replication viable virus, which can provide for the replenishment of the population of infected cells in the future. The second element for qualifying as a viral reservoir is stability; where viruses can persist either as virions or in infected cells in order to safeguard the future continuation of viral progeny in the host.

\section{Tissue and cellular reservoirs of HIV}

Two major reservoirs for HIV have been recognized: anatomical and cellular. A viral reservoir may be defined as an anatomical site or cell type in which a replicationcompetent form of HIV persists, accumulating with more stable kinetic properties than the circulating pool of actively replicating virus. ${ }^{6,9} \mathrm{~A}$ reservoir can be classified as latent, if the infected cells are not producing virus but retain the capacity to do so. HIV has been shown to target many different cell types, and a number of major tissue reservoirs of the virus are evident within infected individuals. The ability of the virus to colonize diverse cellular and tissue targets contributes strongly to persistence in the setting of HAART, and is responsible in part for the emergence of antiretroviral drug resistance.

\section{Tissue reservoirs}

A number of anatomical sites may act as reservoirs of HIV replication including the lymphoid tissue, gastrointestinal tract, brain/central nervous system (CNS), genital tract, semen, and the lung. ${ }^{10-15}$ These structures are immunologically sheltered or separated by a barrier from the blood and lymphoid systems. Some anatomical sites may be non-permissive to immune surveillance and effective drug penetration, thus serving as potential sites of persistent HIV replication eg, the respiratory, gastrointestinal, and reproductive tracts. These reservoirs are either established early in the course of HIV infection or during HAART. 8,16 Differential viral evolution in these sites as compared to the blood compartment has been observed, and may be indicative of the significance of these sites to whole body HIV 
replication. ${ }^{15}$ The optimal delivery of antiretroviral therapies to these different anatomical sites is also important in the context of both viral eradication and preventing the emergence of drug-resistant HIV variants.

\section{Peripheral lymphoid tissue}

HIV generally enters the human host via mucosal surfaces and is subsequently disseminated throughout the lymphatic tissues, which then become a major reservoir of virus throughout the course of infection. ${ }^{17-19}$ Initial colonization of lymphoid tissue is thought to be mediated by dendritic cells (DCs) and macrophages, which associate with the virus at the mucosal surfaces and transport it to the lymph nodes where the initial infection of $\mathrm{CD}^{+} \mathrm{T}$ lymphocytes occurs. Although lymphoid tissues are considered the primary site of $\mathrm{CD}^{+} \mathrm{T}$ cell infection over the course of the disease, follicular dendritic cells (FDCs) are the major source of viral RNA in lymphoid tissue. Measurement of viral pools in lymphoid tissue during the asymptomatic phase of infection has revealed an extremely large FDC pool of approximately 1011 copies of viral RNA, exceeding the viral RNA in productively infected cells by more than 50 fold. ${ }^{20}$ The level of HIV-1 RNA in virions associated with FDCs is also two orders of magnitude greater than plasma levels during this phase of infection. ${ }^{20}$ This indicates that the measurement of plasma HIV levels greatly underestimates the viral burden and that lymphoid tissue is a major reservoir site where HIV is stored. In the later stage of infection, there are comparable quantities of virus stored in the FDC pool, ${ }^{21}$ although earlier in infection the FDC pool is somewhat smaller and closer in size to the viral load in productively infected cells. In addition to viral burden, lymphoid tissue is the major site of HIV production in the body..$^{20,21}$

The pattern of productive infection in lymphoid tissue is consistent with cell-to-cell transmission from one cell to another activated $\mathrm{T}$ cell in its vicinity. ${ }^{22}$ The localized nature of virus production in lymphoid tissue is implied by observations of foci of infected cells, ${ }^{17}$ and evidence of founder effects in viral populations derived from single white pulps. ${ }^{22,23}$ The inhibitory effect of HAART on both viral replication and the levels of virus in the blood and in lymphoid tissues is well documented, and has been consistent over a number of studies. ${ }^{21,24-26}$ Little or no viral RNA is detectable in the FDC pool, in total RNA extracted from lymphoid tissue, or in cells isolated from lymphoid tissue, when plasma viremia is suppressed to below detectable levels. However, chronically and latently infected $\mathrm{CD}^{+} \mathrm{T}$ cells persist ${ }^{24}$ and represent potential focal points of viral reproduction upon cessation of therapy. ${ }^{5}$
In addition, chronically infected cells and replication of less fit drug-resistant viruses result in the continued evolution of genotypic drug resistance. ${ }^{27}$

\section{The gastrointestinal tract}

The gastrointestinal tract mucosa is the largest lymphoid organ in the body. ${ }^{28}$ Due to a large population of activated CXCR $4^{+}$ $\mathrm{CCR}^{+}$target cells, the gastrointestinal mucosa represents a favored target for HIV-1 infection ${ }^{29}$ and appears to support enhanced HIV-1 replication in comparison to other body compartments. ${ }^{30-32}$ With the exception of parenteral transmission, almost all vertical and homosexual transmission of HIV occurs via the gastrointestinal tract. Virus inoculated into the gastrointestinal tract of the fetus or infant is likely to enter the gut associated lymphoid tissue through tonsillar and/or upper intestinal mucosa. Homosexual transmission of the virus occurs through orogenital or anogenital contact. The efficiency of HIV transmission across the gastrointestinal mucosa depends upon factors including: donor blood viral levels; ${ }^{33,34}$ the pre-existence of genital tract infection and local inflammation; ${ }^{35}$ mucosal integrity; genetic predisposition; and behavioral factors. Potential cellular routes in the translocation of HIV across the epithelium include: mucosal cells, ${ }^{36,37}$ DCs; $;^{38}$ and epithelial cells. ${ }^{39}$ Epithelial cells appear to be the most predominant viral transfer mechanism, selectively transporting R5 tropic viruses, which are the predominant phenotype of the majority of transmitted viruses. ${ }^{39}$

The gastrointestinal mucosa contains a large proportion ( $40 \%-60 \%)$ of the body's lymphocyte population ${ }^{40}$ and is the largest reservoir for macrophages in the body. ${ }^{41}$ Furthermore, the majority of mucosal $\mathrm{CD}^{+}{ }^{+} \mathrm{T}$ lymphocytes are of the activated memory phenotype ${ }^{42}$ providing a ready target for HIV-1 infection. ${ }^{43}$ This heightened state of cellular activation arises from elevated levels of pro-inflammatory cytokines released in response to foreign antigens and bacterium. Several studies have demonstrated that in addition to similar levels of CXCR4 expression, mucosal mononuclear cells have a higher predominance of CCR 5 expression than peripheral blood cells, thus increasing susceptibility to infection by primary HIV-1 isolates. ${ }^{44}$ Although large numbers of intestinal macrophages exist in the subepithelial lamina propria, these differ markedly in phenotype and function from blood monocytes, ${ }^{45,46}$ and are poorly permissive to HIV infection. ${ }^{47}$ Although the prevalence of $\mathrm{HIV}$-infected macrophages in the mucosa is low $(0.06 \%$ of lamina propria mononuclear cells $),{ }^{48}$ the extremely large size of the gastrointestinal mucosa makes intestinal macrophages a prominent reservoir of HIV. In contrast, epithelial lymphocytes express CXCR4 and CCR5 
and support replication by X4 and R5 viruses, ${ }^{39,49}$ and it is likely that these are the initial target cell for HIV after upper gastrointestinal tract inoculation. From the mucosa, virus is disseminated to systemic sites initiating large-scale depletion of $\mathrm{CD}^{+} \mathrm{T}$ cells first in the intestinal lamina propria and subsequently in the blood.

\section{The central nervous system}

The CNS is a key anatomical reservoir of HIV-1 in both therapy-experienced and therapy-naïve patients. ${ }^{16}$ The CNS is protected by two formidable barriers: the blood-brain barrier which tightly segregates the brain from the circulating blood, and the blood-cerebrospinal fluid barrier in the epithelium of the choroid plexus, which limits the passage of molecules and cells into the cerebrospinal fluid. This barrier-mediated separation of the CNS gives rise to an altered immunological environment, and also provides an obstacle to therapeutic measures such as antiretroviral therapy. For these reasons, the CNS represents a unique site for viral replication in HIV-infected patients, particularly in the setting of HAART. ${ }^{16}$

HIV enters the CNS early in the course of systemic infection, ${ }^{50}$ and is present at all subsequent stages. As a result of CNS infection, patients may suffer from a range of clinical symptoms, the most notable being dementia. ${ }^{51}$ Prototype HIV-1 isolates from the CNS are typically R5 nonsyncytium inducing $\mathrm{M}$ tropic strains. Macrophages and microglia are the principle target cells for productive infection in the CNS. ${ }^{52,53}$ Both infection and activation of these cell types appears to be critical for the development of dementia. ${ }^{54}$ Recently, HIV DNA has been detected in cortical and basal ganglia-derived astrocytes, and it is believed that astrocytes may serve as a viral reservoir in the brain. ${ }^{55}$ Gene microarray analysis has shown that HIV-1 alters the programme of gene expression in astrocytes, including changes in transcripts encoding cytokines. HIV infection also inhibits the capacity of astrocytes to clear glutamate, a feature likely to affect neuronal activity or survival and contribute to HIV neuropathogenesis. ${ }^{56}$ Although there is no firm in vivo evidence that neurons can support HIV-1 infection, recent in vitro experiments have demonstrated the ability of neurons to sustain transient productive infection for brief time periods. $^{57}$

The mechanisms of HIV-1 penetration into the CNS are uncertain. Some evidence exists that HIV-infected bone marrow-derived monocytes may transport HIV across the blood-brain barrier. ${ }^{58,59}$ Blood-derived microglia have also been suggested to transport HIV across the blood-brain barrier. ${ }^{60}$
A second putative mechanism of HIV entry into the CNS is a mechanism involving the passage of HIV from the blood to the cerebrospinal fluid, then into the choroid plexus and ventricles and thus into the brain. Supporting this, productive viral infection occurs in the choroid plexus, predominantly in stromal macrophages and DC. ${ }^{61-64}$ The incidence of HIV-1 infection in the choroid plexus exceeds that of the brain, and also occurs prior to the onset of AIDS and immunosuppression. ${ }^{63}$ It is thought that the greater vascular permeability of the choroid plexus may render it more susceptible to HIV-1 infection, and may facilitate heterogeneous dissemination of the virus to the brain. Supporting this, studies have shown that choroid plexus HIV sequences are admixtures of brain-and bloodderived isolates ${ }^{65}$ and are common in asymptomatic HIVinfected patients. ${ }^{66}$ Due to the presence of the blood-brain and blood-cerebrospinal fluid barriers, suppression of HIV populations in the CNS with antiretroviral drugs is problematic. Drug penetration into the CNS is poor, and the maintenance of effective drug concentrations is difficult. These are some of the problems influencing the treatment of HIV infection in the CNS.

\section{Reproductive tract}

Both the male and female genital tracts are potential reservoirs for HIV. Each has a distinct microenvironment that permits viral replication independent from the systemic circulation. ${ }^{67,68}$ The male genital tract possesses unique vascular features, including the blood-testis barrier, formed by specialized tight junctional complexes between Sertoli cells that prevent free ingress of substances from the testicular interstitium to the seminiferous epithelium. ${ }^{69}$ In addition to cell-free HIV particles, T lymphocytes and macrophages isolated from semen of HIV-infected men harbor provirus. ${ }^{70,71}$ A differential source of virus in semen and blood has been suggested by a number of studies, providing evidence that the male reproductive tract is a distinct reservoir of virus in HIVinfected men. An absence of correlation between plasma and semen viral loads has been reported by several investigators suggesting independent viral replication. ${ }^{72,73} \mathrm{HIV}$ infection of the testis has been described, ${ }^{74}$ and CD4 is detectable on the cell surface of lymphocytes and macrophages infiltrating the testis, suggesting these cells are potentially infectable by HIV. ${ }^{75}$ HIV-infected cells of the lymphocytic/monocytic type have been found in seminiferous tubules and interstitium of the testis, and these cells were also observed in semen. ${ }^{75}$ Other possible targets of HIV infection in the testis include spermatogonia, spermatocytes and spermatids, ${ }^{76,77}$ and residual germ cells. ${ }^{78}$ 
Multiple cells and tissues in both the upper and lower female reproductive tract are susceptible to HIV infection, ${ }^{79}$ and histopathological studies have clearly demonstrated the genital tract of HIV-infected women is an active site for viral replication, especially in the submucosa of the cervical transformation zone.$^{80} \mathrm{HIV}$ infection has been demonstrated in a range of tissues within the female genital tract, including: epithelial and stromal cells of the uterus and fallopian tube; cervix; and ectocervix. ${ }^{79}$ Virus in the genital tract of HIV-infected women also has its own dynamics that are partly independent of the systemic compartment, supporting the female genital tract as an HIV reservoir. ${ }^{80}$ Genital tract shedding has been found to occur in women on HAART with less than 500 viral copies per milliliter of plasma, suggesting a separate reservoir of HIV-1 replication. ${ }^{81}$

\section{The lung and kidneys}

Both the lung and kidneys have been suggested to act as reservoirs of virus in HIV-infected individuals, however, the significance of these organs during the course of disease remains uncertain. HIV can be detected frequently and recovered from both alveolar macrophages and alveolar lymphocytes. ${ }^{82,83}$ HIV is most commonly recovered from the alveolar lymphocytes indicating that the virus is carried into the lungs by these cells as they migrate from the blood in response to opportunistic infections. Although distinct populations of the virus have been detected between the blood and lung, more homogeneous populations have been detected in the lung with low copy number suggesting a lack of replication. The low level of RNA detected in alveolar macrophages also suggests the lung is of limited importance as a site of HIV replication. ${ }^{83,84}$ However, larger amounts of HIV RNA have been detected in bronchoalveolar lavage fluid. ${ }^{85,86}$ Some discordance between drug resistance mutations in the RT gene of HIV from bronchoalveolar lavage fluid and plasma has also been reported. ${ }^{86}$

The kidney represents another site of localized HIV replication, and has been an organ of particular interest due to the occurrence of HIV-associated nephropathy. Renal glomerular and tubular epithelial cells have been shown to harbor both HIV DNA and mRNA, suggesting productive infection. ${ }^{87,88}$ Circularized viral DNA has also been found in kidney biopsies suggesting active replication in renal tissue, although infiltrating infected leukocytes harbor more viral mRNA than renal epithelium. ${ }^{87}$ Productive HIV infection in renal epithelial cells was recently confirmed by in situ hybridization polymerase chain reaction (PCR), and phylogenetic analyses of kidney-derived sequences conducted in the same study revealed evidence of tissue-specific evolution when compared to those of peripheral blood mononuclear cells.$^{88}$ The combination of productive and independent HIV infection in a localized manner within the renal tissue suggests the existence of a renal viral reservoir.

\section{Cellular targets and reservoirs}

A wide-range of cell types distributed amongst a number of different tissues are susceptible to HIV infection. CD4 $4^{+}$ T lymphocytes ${ }^{89}$ and macrophages ${ }^{90}$ are the primary cellular targets of HIV. Other infectable cell types include: monocytes, $\mathrm{CD}^{+} \mathrm{T}$ lymphocytes; natural killer (NK) cells; peripheral blood and FDCs; B cells; and an array of specialized cell types derived from various tissue reservoirs of HIV (eg, renal, mucosal, and cervical epithelial cells; astrocytes and microglia in the CNS; skin fibroblasts; and bone marrow stem cells). However, the infection of a number of putative cellular HIV targets remains controversial, and a contribution to HIV pathogenesis is often unclear.

\section{$\mathrm{CD} 4^{+} \mathrm{T}$ lymphocytes}

The hallmark of HIV-1 infection is the progressive depletion of $\mathrm{CD}^{+} \mathrm{T}$ lymphocytes. $\mathrm{CD} 4^{+} \mathrm{T}$ cell tropic HIV strains are designated $\mathrm{X} 4$ viruses as they predominantly use the CXCR4 co-receptors for cellular entry. X4 viruses are associated with increased replication, and syncytium inducing infection..$^{91}$ Reflecting this, HIV infection of $\mathrm{CD}^{+} \mathrm{T}$ cells is cytopathic and leads to extensive cell death. ${ }^{92}$ CXCR4 4 is widely expressed and present on both naive and memory $\mathrm{CD} 4^{+} \mathrm{T}$ cells. ${ }^{93} \mathrm{HIV}$ entry and subsequent replication in $\mathrm{CD} 4^{+} \mathrm{T}$ cells requires cellular activation, ${ }^{94}$ which leads to an increase in the size of the nucleotide pool required for viral DNA synthesis and the level of transcription factors. ${ }^{94}$ The majority of $\mathrm{CD}^{+}$ $\mathrm{T}$ lymphocytes in the blood are in a resting non-activated state and thus are not susceptible to infection. ${ }^{95}$ Despite this, $\mathrm{CD}^{+} \mathrm{T}$ lymphocytes are still the principle cellular reservoir of HIV.

HIV-1 infection of $\mathrm{CD}^{+} \mathrm{T}$ lymphocytes is thought to occur predominantly in lymphoid tissue, where there is close contact with other infected leukocytes including antigen presenting cells. ${ }^{19,96}$ The pattern of productive infection in lymphoid tissue is consistent with cell-to-cell transmission, from one cell to another activated $\mathrm{T}$ cell in its vicinity. ${ }^{22}$ Within lymph nodes, germinal centre $\mathrm{CD} 4{ }^{+} \mathrm{T}$ cells represent an important site of HIV replication in vivo. ${ }^{97}$ Lymphoid tissue biopsies from HIV-infected patients have also suggested that $\mathrm{CD}^{+} \mathrm{T}$ cells remain the major source of HIV-1 production in the end-stage of the disease..$^{98}$ The 
gastrointestinal tract is a major site of $\mathrm{CD}^{+} \mathrm{T}$ cell depletion and HIV replication..$^{99} \mathrm{~A}$ large proportion of the body's lymphocyte population resides in the gastrointestinal mucosa, ${ }^{40}$ and the intestine contains an abundance of activated memory $\mathrm{CD}^{+} \mathrm{T}$ cells, which are favored targets of HIV infection. $\mathrm{CD}^{+}{ }^{+} \mathrm{T}$ cells are also likely to become infected in the thymus, ${ }^{100}$ and the depletion of $\mathrm{CD}^{+}$thymocytes through the destruction of $\mathrm{CD} 4^{+} / \mathrm{CD} 8^{+}$precursor cells may play a significant role in the pathogenesis of HIV-1 disease. Analyses have demonstrated the emergence of cytopathic and tissue-specific HIV variants in the thymus. ${ }^{100}$ Furthermore, CXCR4 expression is modulated during T-lymphoid differentiation such that immature thymocytes display an increased frequency and higher surface density of the coreceptor than do more mature cells. ${ }^{101}$ High levels of both primary receptor and coreceptor may therefore be responsible for the efficient infection of the thymus, and could in part account for the rapid disease progression observed in HIV-infected children, where the thymus is actively involved in the production of new T lymphocytes. ${ }^{101}$

Much debate exists over the mechanisms of $\mathrm{CD}^{+} \mathrm{T}$ cell depletion by HIV. At the outset, it is important to realize that the fall in $\mathrm{CD}^{+}$numbers is not only a result of $\mathrm{CD}^{+}{ }^{+} \mathrm{T}$ cell destruction, but also stems from impaired production. Early suggestions of cytopathic destruction of $\mathrm{CD}^{+} \mathrm{T}$ cells $\mathrm{s}^{102,103}$ were complicated by observations that there were many more cells dying than there were infected cells. It was soon realized that a number of other mechanisms were responsible for $\mathrm{CD}^{+} \mathrm{T}$ cell death and the subsequent decline in numbers. Both the destruction of mature $\mathrm{CD} 4^{+} \mathrm{T}$ cells and the impaired production of new cells can be attributed to both direct and indirect effects of the virus.

One of the central immunological defects in HIV-infected individuals is a weak or absent $\mathrm{CD} 4^{+} \mathrm{T}$ helper proliferative response. ${ }^{104}$ When present these responses correlate directly with decreased plasma viremia. The clinical stages of HIV disease are also firmly linked with the $\mathrm{CD} 4^{+} \mathrm{T}$ cell dynamics over time during the infection. $\mathrm{CD} 4^{+} \mathrm{T}$ cell numbers decline sharply during the acute phase of infection, partially rise again and then slowly decline once more during the asymptomatic phase until counts fall below 200 cells per microliter of blood, which marks the progression to AIDS. The emergence of CD4-tropic (X4) viruses is associated with rapid $\mathrm{CD} 4^{+} \mathrm{T}$ cell decline and disease progression. ${ }^{105}$ In the years after chronic infection is established, X4 strains emerge in approximately $50 \%$ of infected individuals. The association between X4 virus and acceleration of HIV-1 disease progression has been attributed to the expanded spectrum of $\mathrm{CXCR} 4^{+}$precursor cells susceptible to infection by $\mathrm{X} 4$ strains. It has also been postulated that the decline of the host immune system associated with clinical AIDS may allow X4 viruses to evolve and replicate more freely in later stages of infection. ${ }^{105}$ The establishment of latent HIV infection in resting memory $\mathrm{CD} 4^{+} \mathrm{T}$ cell subsets early in infection is of primary importance in the persistence and continued evolution of HIV, particularly in the setting of potent antiretroviral therapy.

\section{Emerging concepts on central memory and transitional memory $\mathrm{CD} 4^{+} \mathrm{T}$ cells}

New data shows that the central memory (TCM) and transitional memory (TTM) $\mathrm{CD}^{+}{ }^{+} \mathrm{T}$ cells define major cellular reservoirs for HIV, where viral persistence occurs by two different mechanisms. Primarily, HIV persists in the TCM cells in subjects showing reconstitution of the $\mathrm{CD} 4^{+}$ compartment upon HAART. The maintenance of this reservoir is through $\mathrm{T}$ cell survival and low-level antigen-driven proliferation, which is slowly depleted over time. In contrast, preferential detection of proviral DNA is a feature of TTM cells from aviremic individuals with low $\mathrm{CD}^{+}$counts and higher amounts of interleukin-7-mediated homeostatic proliferation. This mechanism ensures persistence of these cells in vivo. Chomont and colleagues ${ }^{106}$ have identified two viral reservoirs within the memory $\mathrm{CD} 4^{+} \mathrm{T}$ cell subsets of virally suppressed subjects. The TCM reservoir is the major long-lasting reservoir in immune responders to HAART. As TCM cells are characterized by their extremely low degree of cellular proliferation, and, because of their intrinsic capacity to survive for decades, these cells provide a long-lasting cellular reservoir for HIV-1.

The second paper, by Brennan and colleagues, ${ }^{107}$ uses genetic analyses of HIV sequences to show that there is a reservoir of virus that seems to be coming from a cell type other than memory $\mathrm{CD} 4^{+} \mathrm{T}$ cells. This study shows that in most cases, the residual virus detectable in individuals on suppressive ART is genetically distinct from the virus found in the memory CD4 T cells. Therefore, if much of the residual viremia in HIV patients on HAART arrives from other reservoir sites, as suggested, the eradication strategies need to be revisited for purging reservoir virus.

\section{$\mathrm{CD}^{+} \mathrm{T}$ lymphocytes}

Although debate still exists over the significance of HIV infection of $\mathrm{CD}^{+} \mathrm{T}$ lymphocytes, there is little doubt that HIV can productively infect these cells. Reports of CD $8^{+}$ $\mathrm{T}$ cell infection have occurred on a regular basis since the 
early stages of the epidemic. Initially, $\mathrm{CD}^{+} \mathrm{T}$ cell infection was described in vitro. ${ }^{108}$ These reports were followed by evidence that $\mathrm{CD}^{+} \mathrm{T}$ cells harbor and express HIV-1 in vivo, ${ }^{109}$ and may express small amounts of $\mathrm{CD}^{+}{ }^{+} \mathrm{RNA} .{ }^{109}$

Much of the research conducted on the HIV infection of $\mathrm{CD}^{+} \mathrm{T}$ cells has focused on the mechanism of viral entry, and the origins of $\mathrm{CD}^{+}$cell infection. Evidence suggests that $\mathrm{CD}^{+} \mathrm{T}$ cells become infected through a conventional CD4-dependent mechanism during their maturation in the thymus, at the double-positive (DP) stage where CD4 is co-expressed with CD8. Implants of human thymic tissue containing infected DP thymocytes in severe combined immunodeficiency (SCID) mice have been shown to produce infected single positive (SP) $\mathrm{CD}^{+} \mathrm{T}$ lymphocytes in the peripheral circulation. ${ }^{110} \mathrm{HIV}-1$ proviral DNA is also preferentially distributed in the naïve $\left(C D 45 \mathrm{RA}^{+}\right)$subset of $\mathrm{CD}^{+} \mathrm{T}$ cells, further supporting the thymus as a source of $\mathrm{CD}^{+} \mathrm{T}$ cell infection. ${ }^{111}$

In addition to possible intrathymic mechanisms, stimulation of highly purified $\mathrm{CD}^{+} \mathrm{T}$ cells with mitogens, allogeneic DC or anti-CD3 and anti-CD28 antibodies in vitro leads to de novo synthesis of CD4 and susceptibility to HIV-1 infection. ${ }^{112}$ Activated subsets of circulating $\mathrm{CD}^{+} \mathrm{T}$ lymphocytes express high frequencies of CD4 in vivo, rendering these cells vulnerable to viral destruction. ${ }^{13,115}$ Reports of $\mathrm{CD}^{+}$-mediated CD4 independent entry into $\mathrm{CD} 8^{+}$ $\mathrm{T}$ cells have also been provided by Saha and colleagues. ${ }^{115}$ Multiple $\mathrm{CD}^{+}$clones generated from patients with AIDS were characterized and it was found that several were CD8 single positive and endogenously infected by HIV. ${ }^{115}$ Subsequent biological characterization of these isolates demonstrated CD8-mediated cell entry without the requirement for any known chemokine coreceptor. ${ }^{115}$ Recent work by this group has lead to further characterization of CD4independent entry. ${ }^{115}$

In addition to clarification of $\mathrm{CD}^{+} \mathrm{T}$ cell entry mechanisms, several studies have focused on quantitative aspects of $\mathrm{CD}^{+}{ }^{+}$infection by HIV. Several reports have sought to compare the abundance of HIV provirus in $\mathrm{CD} 8^{+}$cells with those of other leukocytes. It has been concluded that $\mathrm{CD}^{+} \mathrm{T}$ cells harbor substantial amounts of provirus. Livingstone and colleagues found that in the late stages of the disease, infection in $\mathrm{CD}^{+} \mathrm{T}$ cells accounts for between $66 \%$ and $97 \%$ of total proviral DNA; there is an inverse relationship between $\mathrm{CD} 8^{+} \mathrm{T}$ cell counts and the frequency of $\mathrm{CD}^{+} \mathrm{T}$ cell infection. ${ }^{116}$ Similarly, more recent reports have found that $\mathrm{CD}^{+} \mathrm{T}$ cells contain significant amounts of provirus. ${ }^{111,113}$ Additional studies have also attempted to clarify the distribution of proviral DNA in specific $\mathrm{CD} 8^{+} \mathrm{T}$ cell subsets. One report demonstrated preferential distribution of HIV in the naive $\left(\mathrm{CD}^{2} 5 \mathrm{RA}^{+}\right)$subset of $\mathrm{CD}^{+} \mathrm{T}$ cells compared to the memory/effector $\left(\mathrm{CD} 45 \mathrm{RO}^{+}\right)$population. In contrast to all previous findings, one recent report has suggested that naïve and memory $\mathrm{CD}^{+} \mathrm{T}$ cells are rarely infected by HIV. ${ }^{113}$

Currently there is debate over whether the infection of $\mathrm{CD}^{+} \mathrm{T}$ cells contributes significantly to the immunodeficiency observed in AIDS. This stems from the existence of a number of other possible mechanisms that could account for the numerical decline and functional impairment of $\mathrm{CD}^{+}$cells observed in the progression of the disease. These include increased susceptibility to apoptosis from alterations in the cytokine milieu in lymphoid tissue; bystander effects from neighboring productively infected $\mathrm{CD}^{+} \mathrm{T}$ cells, or toxicity from the release of HIV derived proteins such as gp120 or Tat. ${ }^{117}$ Loss of $\mathrm{CD}^{+}$helper function leading to impaired clonal expansion and function of $\mathrm{CD}^{+} \mathrm{T}$ lymphocytes on antigenic pressure also contributes. ${ }^{118}$ Thymic destruction of CD8 precursor cells has been proposed as an explanation for the eventual failure of CD8 homeostasis; the decline in circulating numbers of first naïve and then memory $\mathrm{CD}^{+} \mathrm{T}$ cells upon disease progression; ${ }^{119}$ and the recovery in naïve $\mathrm{CD}^{+}$numbers on commencement of antiretroviral therapy. ${ }^{120}$

\section{Macrophages}

Macrophages represent a key target of HIV in addition to $\mathrm{CD}^{+} \mathrm{T}$ lymphocytes. Although CD4 surface expression on macrophages is lower than on $\mathrm{CD}^{+} \mathrm{T}$ cells, and the number of infected macrophages in the body is relatively low in comparison, ${ }^{121}$ macrophages still produce large amounts of virus. ${ }^{122} \mathrm{HIV}$ in macrophages is produced on the complex surfaces between cells, on free surfaces, and in cytoplasmic vacuoles of the Golgi apparatus. ${ }^{123}$ In addition to producing new virions, macrophages spread viral particles to bystander $\mathrm{CD}^{+} \mathrm{T}$ lymphocytes through a fusion mechanism, ${ }^{124}$ and activation of the oxidative pathway in infected macrophages may also lead to apoptotic death of noninfected bystander cells. $^{117}$

Macrophages are a primary agent of viral dissemination with a widespread distribution, and are the principal infected cell type in many tissues (eg, CNS). ${ }^{125}$ Macrophage HIV isolates (M-tropic) are predominantly R5 strains, associated with slower and nonsyncytiumni-inducing infection. ${ }^{126}$ The infection of macrophages is predominantly mediated through CCR5, and M-tropic variants are 
preferentially transmitted. ${ }^{127}$ Although macrophages have been shown to express CXCR4, ${ }^{128}$ they are believed to impose a restriction on the replication of $\mathrm{X} 4$ virus at the intracellular level. ${ }^{129}$

Macrophages provide a different environment for HIV that is distinct from the milieu in lymphocytes. In contrast to lymphocytes, macrophages are in a stage of terminal differentiation and have a limited potential for proliferation. ${ }^{130}$ They are insensitive to the cytopathic effect of the virus, and the long life span of infected macrophages probably compensates for their relatively low number, substantiating their contribution to viral production. ${ }^{131}$ Short-term dynamics in productively infected $\mathrm{CD} 4^{+} \mathrm{T}$ cells are characterized by a rapid exponential increase of virus replication followed by extensive cell death. In contrast, macrophages can produce and release high levels of the virus over an extended time period, ${ }^{132}$ categorizing them as chronically and persistently infected cells. ${ }^{6}$ Signal transduction pathways in macrophages differ substantially from those of T cells. Such pathways can be modulated by HIV and contribute to the regulation of cell susceptibility to infection. ${ }^{133}$ For example, different CD45 isoforms are expressed by naïve and memory $\mathrm{CD} 4^{+} \mathrm{T}$ cell subsets. The signal transduction molecule p56lck is present on $\mathrm{CD}^{+} \mathrm{T}$ cells but absent on macrophages, correlating with CD4 endocytosis in macrophages. ${ }^{134}$ There are differences in the infectivity of viruses produced by macrophages, ${ }^{125}$ and limited nucleotide precursors in macrophages can result in an increased time period for viral replication. ${ }^{135}$ However, some studies have shown similar kinetics in both macrophages and lymphocytes, ${ }^{136}$ while others have demonstrated that primary isolates replicate at higher levels in macrophages compared to $\mathrm{T}$ cells. ${ }^{137}$

Although macrophages are most likely to be a significant source of HIV during the second, slower phase of decay, ${ }^{138}$ it has been suggested that latent infection may be established in macrophages. Latently infected macrophages have been observed in large numbers throughout the lymphoid system from the early to late stages of infection. ${ }^{139}$ In addition, the unusual dynamics of replication in macrophages and the unique characteristics of these cells result in altered responses to antiretroviral therapy.

\section{Monocytes}

HIV infection of circulating blood monocytes was reported early in the epidemic. ${ }^{140}$ These initial reports made it unclear as to whether monocyte infection is latent or productive. Subsequent studies found levels of proviral DNA in monocytes to be relatively low or undetectable in comparison to T cell compartments. ${ }^{141}$ However, more sophisticated approaches using in situ hybridization coupled with simultaneous surface immunophenotyping revealed a higher incidence of monocyte infection, and demonstrated the production of viral mRNA in monocytes indicating productive infection. ${ }^{142}$ Despite the apparent production of viral mRNA, other in vitro studies indicated that HIV replication was blocked prior to reverse transcription and integration. ${ }^{143}$ Following this, replication-competent virus was shown to be recoverable from blood-derived monocytes upon stimulation and differentiation into macrophages. ${ }^{144}$

Recent studies have investigated the levels of cellassociated viral DNA, mRNA and the genetic evolution of HIV over the course of infection. ${ }^{145}$ Monocytes isolated from blood have been shown to contain unintegrated circular viral DNA and multiply spliced RNA suggesting their infection is recent and transcriptionally active rather than latent. ${ }^{146} \mathrm{Zhu}$ and colleagues observed that blood-purified monocytes harbored HIV DNA over time in both untreated and therapy-suppressed individuals. ${ }^{145}$ Viral decay in monocytes was considerably slower on average than that in activated and resting $\mathrm{CD}^{+} \mathrm{T}$ cells. In addition, the average half-life of HIV DNA in monocytes was considerably longer than the estimated mean intermitotic lifespan of monocytes and macrophages, ${ }^{138}$ suggesting renewal of the virus as a result of continued viral replication. ${ }^{145}$ A significant genetic evolution in monocytes was also observed, and in some individuals on suppressive therapy monocyte strains were phylogenetically linked with circulating plasma variants. ${ }^{145}$ These findings suggest that monocytes may constitute a continuing source of infectious virus during HAART regardless of the length of treatment.

The circulating monocyte population is heterogeneous consisting of several subsets. The majority express high levels of CD14 and little or no CD16, described as CD14hi. ${ }^{147}$ The normal pathways of monocyte migration and trafficking may also define a mechanism by which HIV is distributed to various compartments around the body. After leaving the bone marrow, monocytes remain in circulation for between two and four days before migrating through the endothelial walls of capillaries and undergoing differentiation into tissue macrophages. Alternatively they may differentiate into DCs and enter the lymphatic system. HIV-infected monocytes can thus migrate to a variety of different sites around the body, and are likely to be responsible for colonization and continued turnover in diverse tissue compartments such as the CNS. ${ }^{148}$ The early establishment of HIV infection in 
monocytes and the ongoing replication and persistence of HIV in this compartment represents a considerable challenge for antiretroviral drug regimens.

\section{Dendritic cells}

Dendritic cells (DCs) are professional antigen-presenting cells that play a major role in HIV pathogenesis. Langerhans cells, a DC subset residing in epithelial surfaces such as the skin, act as one of the primary, initial targets for HIV infection. Myeloid DCs (MDCs) and plasmacytoid DCs (PDCs), also professional antigen-presenting cells, are additional targets of HIV. As part of the normal immune response, DCs capture virions at the site of transmission in the mucosa, and migrate to the lymphoid tissue where they are responsible for large-scale infection of $\mathrm{CD}^{+} \mathrm{T}$ lymphocytes. Thus, dendritic- $T$ cell interactions in lymphoid tissue, which are critical in the generation of immune responses, are also a major catalyst for HIV replication and expansion. Exposure of HIV to DCs may also impair the antigen-presenting capacity of these cells resulting in inadequate expansion of HIV-specific T cell responses.

Langerhans cell progenitors are derived from the bone marrow, ${ }^{149}$ and home to epithelial surfaces where they remain in a resting or immature state until they encounter antigens. Immature Langerhans cells possess a highly active endocytic system for efficient antigen processing. ${ }^{150}$ Langerhans cells were the first DCs to be reported as target cells for HIV infection. ${ }^{151}$

Viral attachment to DCs occurs via cell surface interactions that are dissimilar to those of regular HIV infection. Viral attachment to the surface of DCs is mediated by C-type lectins including: DC-SIGN (dendritic cell-specific intercellular adhesion molecule-3-grabbing nonintegrin); ${ }^{152}$ langerin; and the mannose receptor. ${ }^{153}$ Viral attachment via these receptors can be followed by internalization and/or subsequent transfer to permissive T cells. ${ }^{154}$ Internalized HIV can be stored in early endosomal compartments without degradation, while surface-associated HIV can remain infectious for several days and can be transmitted to $\mathrm{CD}^{+} \mathrm{T}$ cells. ${ }^{152,154}$ The migratory nature of DCs and their ability to recruit numerous $\mathrm{T}$ cells to lymphoid tissue identifies them as strong candidates for a central role in spreading HIV within the host. ${ }^{155}$ A large number of DCs accumulate rapidly in the lymphoid tissue in the first weeks after infection, ${ }^{156}$ coinciding with a massive increase in the numbers of productively infected $\mathrm{CD} 4^{+} \mathrm{T}$ cells in the lymphoid tissue. ${ }^{157}$ In addition, HIV replicates in clusters of DCs and $\mathrm{CD}^{+}{ }^{+} \mathrm{T}$ cells in lymphoid tissue throughout the course of the disease. ${ }^{158}$ Reflecting this, the FDC network in lymphoid tissues is a major site of HIV storage in both presymptomatic and the late stages of disease, and FDCs are recognized as the major source of viral RNA in this compartment. ${ }^{16}$

\section{B cells}

During infection with HIV, a large number of virions are detectable in the follicular areas of lymphoid tissues. Most of this virus is trapped on the surfaces of FDCs as immune complexes along the network of dendrites, which play a critical role in antigen mediated interactions with both $\mathrm{T}$ cells and B cells. ${ }^{159} \mathrm{FDC}$ networks in the germinal centers account for the bulk of HIV RNA. ${ }^{96}$ It has recently been demonstrated that B cells in both lymphoid tissue and the peripheral blood carry replication competent virus attached on their surfaces. ${ }^{160}$ The mechanism of B cell binding to the virus is similar to that of DC, involving the binding of HIV-containing immune complexes to $\mathrm{CD} 21$ on the $\mathrm{B}$ cell surface. ${ }^{160,161}$ Virus bound to B cells can efficiently infect activated $\mathrm{CD} 4^{+} \mathrm{T}$ cells through cell-to-cell contact, ${ }^{160}$ and HIV in the form of immune complexes bound to B cells is more stable and more efficiently passed on to $\mathrm{CD}^{+}$ $\mathrm{T}$ cells than free viral particles. These studies led to the suggestion that B cells may represent an important link between trapped virus on FDCs and virus replicating in $\mathrm{CD} 4^{+} \mathrm{T}$ cells.

A more recent study examined the genetic relationships between HIV bound to B cells and viruses in both $\mathrm{CD}^{+} \mathrm{T}$ cells and plasma. ${ }^{162} \mathrm{HIV}$ bound to peripheral blood B cells was found to be closely related to virus in $\mathrm{CD}^{+}{ }^{+} \mathrm{T}$ cells, and more divergent from virus in plasma. ${ }^{162}$ HIV bound to lymph node-derived B cells and $\mathrm{CD}^{+}$ $\mathrm{T}$ cells were similar, and showed an equivalent divergence from HIV bound to peripheral blood B cells. In addition, both were more distantly related to circulating $\mathrm{CD} 4^{+} \mathrm{T}$ cells. ${ }^{162}$ These findings gave evidence of a close association between virus circulating on $\mathrm{B}$ cells and virus replicating on $\mathrm{CD} 4^{+} \mathrm{T}$ cells, and a significant degree of trafficking between viruses from $\mathrm{B}$ cells and $\mathrm{CD} 4^{+} \mathrm{T}$ cells of the lymph nodes. Thus it is likely that in addition to FDCs, B cells may also contribute to ongoing replication by serving as an extracellular reservoir of HIV.

\section{Natural killer cells}

Natural killer (NK) cells are defined phenotypically as a CD3 negative lymphocyte subset that functions as a first line of immune defense. NK cells express surface 
markers including CD56, CD16, CD57, NKR-P1, however these markers may also be expressed on $\mathrm{T}$ lymphocytes. ${ }^{163}$ The majority of NK cells can be discriminated on the basis of CD56 expression, with the majority being CD56dimCD16 ${ }^{+}$, which have a higher cytotoxic potential. The smaller CD56brightCD16dim/neg NK cell subset has higher cytokine producing potential. Resting CD56bright and CD56dim subsets also show differences in their expression of NK receptor repertoires. ${ }^{164} \mathrm{NK}$ cells are pivotal in innate immunity against viruses and tumors. They can spontaneously kill virally infected cells without prior antigen stimulation and thus participate in early immune defense mechanisms prior to the establishment of adaptive responses. NK cells have direct cytotoxic and also perform non-cytolytic functions such as the secretion of cytokines which later modulate adaptive responses. ${ }^{164}$

Recently a subset of CD56 $6^{+} \mathrm{CD} 16^{+} \mathrm{CD} 3^{-} \mathrm{NK}$ cells was identified which express both CD4 and the chemokine coreceptors CCR5 and CXCR4. ${ }^{165}$ This previously uncharacterized NK cell subset was shown to be productively infected in vitro by both $\mathrm{X} 4$ and $\mathrm{R} 5$ strains via a CD4mediated mechanism. Further characterization of NK cells purified from HIV-infected individuals receiving HAART demonstrated the presence of viral DNA, and virus could be recovered from these cells in culture. ${ }^{165}$ Longitudinal analysis revealed persistent infection of this NK cell subset suggested a substantial contribution of viral DNA to the total pool in peripheral blood mononuclear cells, and showed that current antiretroviral therapies fail to eliminate the virus from this compartment. ${ }^{165}$ These findings raise the possibility that early defects in innate immune responses of HIV-infected individuals, ${ }^{166}$ may derive at least in part from the HIV infection of NK cells.

\section{Tissue compartmentalization of HIV}

\section{The central nervous system}

The CNS is one of the best examples of HIV compartmentalization. The CNS is a key anatomical reservoir of HIV in both therapy-experienced and therapy-naïve patients, and independently evolving HIV variants have been detected in diverse areas of the CNS, and which are genetically distinct from those circulating in the blood. ${ }^{167-169}$ HIV gene sequences in the V3 loop may confer neurotropism as well as neurovirulence. ${ }^{65}$ Brain-derived isolates are macrophage tropic and their env sequences tend to exhibit negative or neutral charges compared to those in the blood.
As discussed previously, the CNS is protected by the blood-brain barrier which tightly segregates the brain from the circulating blood, and the blood-cerebrospinal fluid barrier in the epithelium of the choroid plexus, which limits the passage of molecules and cells into the cerebrospinal fluid. This barrier-mediated separation of the CNS gives rise to an altered immunological environment, and also provides an obstacle to therapeutic measures such as antiretroviral therapy. Much of the HIV compartmentalization arising in the CNS relates directly to antiretroviral drug resistance. This primarily stems from inadequate drug penetration into the CNS, a major shortcoming of current HAART regimens. Inadequate drug penetration into the CNS is of concern firstly as the CNS may form a drug sanctuary for HIV, and secondly because the suboptimal concentration of drugs in this compartment favors the emergence of drug resistance.

HIV protease inhibitors have limited penetration into the brain. This poor transport through the blood-brain barrier is mainly due to active efflux by proteins; such as $\mathrm{P}$-glycoprotein (P-gp), which prevent drugs from clearing virus from the CNS. ${ }^{170,171}$ Most protease inhibitors (PIs), including ritonavir and saquinavir, are P-gp substrates. ${ }^{170,171}$ P-gp is an active drug-transporter of the ATP binding cassette transporter family and possesses a wide substrate range. ${ }^{172}$ As P-gp transports its substrates in an outward (extracellular) direction, it blocks PIs from moving across the blood-brain barrier. ${ }^{170,173}$ Humans have only one drug-transporting P-gp, MDR1, which seems to carry out the same functions as the mouse Mdr1a and Mdr1b P-gps. ${ }^{170}$ The poor penetration of different antiretroviral drugs extends to different regions within the brain, which also show variability in the distribution of antiretroviral drug resistance. ${ }^{174}$ Regional variability in the incidence and frequency of HIV encephalitis lesions have also been described, ${ }^{175}$ and localization of viral RNA and DNA in the brain has also been reported. ${ }^{175}$ However the mechanisms for this viral localization within the brain are still unclear.

\section{Semen and the reproductive tract}

Semen is a complex mixture of fluids from several organs including the testis, epididymis, seminal vesicles, prostrate and seminal ducts. ${ }^{176}$ The fluid component of semen is derived from the accessory glands, and the levels of seminal HIV RNA usually correlate with blood plasma RNA levels, although it has been shown to increase with genital tract inflammation from sexually transmitted diseases. ${ }^{177} \mathrm{HIV}$-infected cells in semen include lymphocytes and macrophages. ${ }^{70}$ The male 
genital tract contains unique vascular features such as the blood-testis barrier. The function of the blood-testis barrier is to protect germ cells from harmful influences; however, it also impedes the delivery of chemotherapeutic drugs to the testis. The barrier has three components: firstly it contains a physicochemical barrier consisting of continuous capillaries; Sertoli cells in the tubular wall, connected together with narrow tight junctions; and a myeloid-cell layer around the seminiferous tubule. Secondly, it has an efflux-pump barrier containing P-gp and multidrug-resistance-associated protein 1 (MDR1); and thirdly, it has an immunological barrier consisting of Fas ligand on Sertoli cells. ${ }^{178}$

These features provide a distinct environment for HIV replication, and hinder access of PIs into the germ cell compartment. Compartmentalization of HIV in the male genital tract has been described by numerous studies based on phylogenetic comparisons between blood and semen, ${ }^{179}$ and the rate and pattern of the emergence of drug resistance in blood and semen. ${ }^{180}$ Distinct resistance patterns are likely to arise from the compartmentalization of viral replication and suboptimal concentrations of drugs in semen.

Studies have found genotypic differences between HIV in blood and HIV in female genital tract secretions. ${ }^{181}$ The mechanisms of this compartmentalization are uncertain, particularly as there is no anatomical barrier to entry in this compartment as in the male genital tract. It is probable that the genetic differences in this location arise from a founder effect, whereby virions migrate to a new tissue and proliferate, followed by localized evolution. ${ }^{182}$ However, selection may also shape the distinct viral populations, ${ }^{183}$ and immune pressures are also likely to contribute. Local conditions including sexually transmitted infections and co-receptor expression on host cells may also be a factor.

\section{Gastrointestinal mucosa}

In addition to the distinctive cellular characteristics of lymphocyte populations in gastrointestinal mucosa, genetic and molecular differences in HIV-1 quasispecies isolated from this compartment have also been demonstrated. Viral isolates from gastrointestinal mucosa have been shown to have a greater propensity to induce cytopathology than blood derived isolates, ${ }^{184}$ and may differ phenotypically with respect to syncytium induction. ${ }^{185}$ Genotypic differences in the env, pro and RT genes have also been reported, ${ }^{186}$ supporting the presence of anatomically distinct, independently evolving viral quasispecies in this compartment. Despite this, a recent study reported that there were no significant differences in viral tropism or co-receptor utilization between isolates from mucosal and peripheral blood mononuclear cell (PBMC) compartments. The pattern of antiretroviral drug resistance in gastrointestinal mucosa has been demonstrated to be similar to that of the PBMC compartment, and in most cases those of plasma viral populations. ${ }^{187}$

\section{Kidney epithelium and lungs}

Recent molecular characterization of HIV quasispecies in the renal compartment has revealed evidence of tissuespecific evolution. Phylogenetic trees constructed from HIV V3-loop or gp120 sequences of HIV DNA derived from renal epithelial cells and PBMC showed that kidneyderived sequences clustered separately within the radiation of blood mononuclear cell-derived viral sequences. ${ }^{88}$ This is best explained by a stochastic event representing a founder effect following the initial seeding of kidney epithelium by a blood-derived variant. ${ }^{88}$

Discordant mutation patterns in the reverse transcriptase and protease genes have been observed in HIV isolates derived from plasma and cell free bronchoalveolar lavage fluid ${ }^{86}$ Likewise, HIV DNA recovered from PBMC and cells from bronchoalveolar lavage fluid showed discordant patterns of drug resistance mutations in some cases. ${ }^{86}$

\section{Cellular compartmentalization of HIV}

\section{Plasma and PBMC}

The archiving of HIV in PBMC complicates the relationship between cell-associated and cell-free HIV circulating in the blood. There are multiple sources of circulating plasma virus in addition to PBMC, and the antiretroviral therapy is likely to suppress viral replication more efficiently in some compartments than others. Longitudinal analyses of plasma HIV RNA and proviral DNA have demonstrated significant differences between the frequencies of envelope sequence variants in the plasma and PBMC populations at any given point-in-time in asymptomatic patients. ${ }^{188}$ Similarly, continual evolution and compartmentalization of HIV drug resistance between plasma and PBMC has been observed over time during HAART. ${ }^{189}$ Another study found that therapy was able to reduce plasma HIV RNA to below the level of detection, but PBMC associated RNA was not suppressed. In addition, CD4 counts correlated more with PBMC HIV RNA levels. ${ }^{190}$ More recently, a report comparing HIV derived from lymph nodes and blood concluded that most of the virus in plasma originated from 
sources other than $\mathrm{CD}^{+} \mathrm{T}$ cells in the peripheral blood and lymph nodes. ${ }^{162}$

\section{Resting memory $\mathrm{CD}^{+} \mathrm{T}$ cells}

The most notable example of HIV compartmentalization at the cellular level is the latent $\mathrm{CD}^{+} \mathrm{T}$ cell reservoir. Compartmentalization of HIV results from these cells remaining inactivated and persisting for long periods of time, which significantly impacts on the ability of HIV to turnover and evolve. Persistently infected, inactivated $\mathrm{CD}^{+}{ }^{+} \mathrm{T}$ lymphocytes ${ }^{191}$ are also a major obstacle to viral eradication. Resting $\mathrm{CD}^{+} \mathrm{T}$ cells harboring provirus have been demonstrated in patients receiving HAART with undetectable plasma virus concentrations for extended time periods, and replication competent virus can be recovered from these cells after $\mathrm{CD} 8^{+} \mathrm{T}$ cell depletion in vitro. ${ }^{192}$ The reservoir is established soon after primary HIV seroconversion, and can be activated by proinflammatory cytokines and bacterial products in vitro and potentially in vivo. The latent replication-competent virus is predominantly found in resting memory $\left(\mathrm{CD}^{+} \mathrm{CD}^{+} 5 \mathrm{RO}^{+}\right)$ cells and at significantly lower levels in resting naïve $\left(\mathrm{CD} 4^{+}\right.$ $\mathrm{CD}^{2} \mathrm{RA}^{+}$) cells. Evidence has shown that virus in the latent $\mathrm{CD} 4{ }^{+} \mathrm{T}$ cell reservoir is mainly CCR 5 tropic, ${ }^{193}$ and contains fewer drug resistance mutations than circulating plasma strains. ${ }^{24}$ These findings are therefore in agreement with the reservoir being established soon after infection. The presence of unintegrated HIV-1 DNA in infected resting CD4+ $\mathrm{T}$ cells from patients with undetectable plasma viremia also suggests persistent and active viral replication in vivo. ${ }^{191}$ This is most likely to be responsible for the continued low-level viral turnover and evolution observed in patients thought to be fully suppressed by HAART. ${ }^{194}$

\section{Macrophages}

Macrophages produce and release high levels of virus over an extended time period, ${ }^{132}$ categorizing them as chronically and persistently infected cells. ${ }^{6}$ They are insensitive to the cytopathic effect of the virus and have an extended long life span. It is unclear whether HIV populations in macrophages are truly compartmentalized, but several features of their infection warrant interest. First and most notably, latent infection is widespread in macrophages throughout the lymphoid system, from early to late stages of infection. ${ }^{139}$ Secondly, it has been shown that there are differences in the infectivity of viruses produced by macrophages, ${ }^{125}$ indicating that HIV may evolve differently in these cells. Finally, the unusual dynamics of replication in macrophages and the unique characteristics of these cells result in altered responses to antiretroviral therapy. Although nucleoside reverse transcriptase inhibitors (NRTIs) are potent inhibitors of HIV replication in macrophages, ${ }^{195}$ PIs show reduced activity requiring much higher dosages for a desirable effect; a feature that could be attributable to P-gp-mediated drug clearance.

\section{Drug penetration, viral reservoirs and drug resistance Poor penetration of antiretroviral drugs in the CNS}

There is considerable evidence showing that unique anatomical structures, which limit the distribution of antiretroviral drugs into the CNS, the blood-brain barrier and the blood-CSF barrier primarily formed by the choroid plexus. High plasma protein-binding of protease inhibitors and their unidirectional efflux by P-gp membrane proteins in the blood-brain barrier limit CNS penetration and absorption of antiretrovirals. ${ }^{170,171}$ Thus, the CNS represents a site where ongoing viral replication may occur. Mutations conferring resistance to multiple antiretroviral drug classes may also predominate in compartments where drug levels are suboptimal.

Suboptimal drug penetration also influences the emergence of multiply drug-resistant variants, which may also predominate in this anatomical reservoir. Discordant changes in the peripheral blood and CSF HIV-1 RNA levels have been reported in response to antiretroviral therapy. Similar and discordant patterns of antiretroviral drug resistance have been detected in the RT and protease genes of isolates from the blood compartment and the CSF of the same patient. ${ }^{196}$ Better understanding of how drug-resistant mutations emerge in HIV populations in vivo, and the development of more efficacious antiretroviral drugs is of paramount importance to achieve and maintain consummate therapeutic drug levels in blood or brain.

\section{Drug penetration in blood leukocytes}

A similar scenario of differential penetration and bioavailability of anti HIV drugs also applies to blood leukocytes. To help ensure that adequate drug concentrations are achieved throughout the dosing interval, therapeutic drug monitoring of the anti-HIV drugs (such as PIs) in plasma is commonly used. The drugs show differential accumulations within lymphoblastoid cell lines and peripheral blood mononuclear cells of virologically suppressed patients in vivo, with: 
nelfinavir $>$ saquinavir $>$ lopinavir $>$ ritonavir $>$ indinavir. Furthermore, drug concentrations in vivo can also vary considerably between cell/tissue types during HAART. ${ }^{197}$ Differences in drug concentrations can be attributed to the variable penetration of antiretroviral drugs which, in turn, is influenced by multispecific drug transporters such as: organic anion transporting polypeptides (OATPs); the MDR1 (P-gp); as well as multidrug resistance-associated proteins (MRP). It is also known that cell lines expressing high levels of P-gp significantly reduce the accumulation of HIV-PI, and are less sensitive to HIV-PI antiviral activity than cell lines not expressing P-gp. ${ }^{198}$ These proteins work in concert with detoxification enzymes to protect the organism/living cells from potentially harmful compounds. ${ }^{16,199}$

\section{Possible relationship between drug transporter concentrations and drug levels}

Recently, Lucia and colleagues ${ }^{200}$ demonstrated differences in the levels of P-gp and MRP in T lymphocytes of HIV patients. They have also shown that protease inhibitors contribute to P-gp efflux function in major cell targets for HIV-1 such as $\mathrm{CD}^{+}$and $\mathrm{CD} 4^{+}$progenitor cells. These data suggest that drug level studies in different cell types of HIV patients are vital to gain a clear understanding of the expression of drug transporter proteins and their relationship with the emergence of cellular drug resistance and drug levels.

\section{New approaches to eradicate viral reservoirs}

It is now apparent that HAART does not provide a complete elimination of HIV from the infected host. If the treatment is stopped, residual virus concealed in several potential reservoir sites can rapidly expand, thereby allowing disease progression to occur. Therefore, investigations concerning the sources of persistent replication-competent HIV during HAART and strategies to purge these reservoirs remain the top priority in HIV treatment. Memory cells are long-lived host cells and HIV can successfully tamper with this unique feature of memory cells and can then persist for decades with its inert and metabolically inactive viral cargo. Upon receiving a stimulatory signal the cell activates, which concomitantly induces the production of viral progeny from the latent HIV genome. T cells also decay very slowly during HAART, with an average half-life of 44 months, and thus it is estimated that with the currently prescribed regimen to HIV patients, complete eradication of this reservoir would take over 60 years. Thus, viral reservoir establishment in HIV patients is a serious obstacle to the long-term success of antiretroviral treatment, especially in those reservoirs that restrict the penetration of various antiretroviral drugs.

There has been considerable interest in developing potential approaches for diminishing, containing and eliminating latent reservoirs of HIV in the infected hosts; however, to date, all these approaches have received skeptical reception at best because of the nature and complexity of viral reservoirs in the human host. Although no successful approach has emerged as a winner in effectively targeting viral reservoir sites, several options for treatments that are targeted at eliminating HIV-infected cells capable of producing replication-competent virus in specific anatomical and cellular reservoirs are presently being explored. As a vaccine is still some distance away from being used as a preventative measure against HIV infection, additional therapies to HAART that target viral reservoirs are clearly needed. These are the treatments that will be aimed at eliminating viral reservoirs or at least preventing their long-term establishment, which can provide a glimmer of hope for the future. Some of these key strategies are discussed below.

\section{Activating persistently and latently infected resting $\mathrm{CD}^{+} \mathrm{T}$ cells}

Given the complexity of pre-integration and post-integration latency in HIV reservoirs, it is difficult to devise a strategy that can provide sustainable eradication of HIV from the reservoir sites, where most of the latent virus is concealed. Most strategies targeting reservoirs involve activating the latently infected cells in order to induce expression from the HIV genome. As a consequence, the cell will become infected and killed either via cytopathic effects induced by HIV or by host immune effector mechanisms. This, in turn, can be a viable platform to halt virus spread through HAART during the stimulation phase. Though a few stimulants are known, interleukin-7 (IL-7), in particular is able to rekindle latent virus from the reservoir site. IL-7 causes a substantial increase in the expression of latent HIV-1 from both human thymocytes and peripheral $\mathrm{T}$ cells with minimal effects on $\mathrm{T}$ cell phenotype. Thus IL-7 remains a viable candidate in the fight for clearance of viral reservoirs. New therapies should target pathways downstream of homeostatic proliferation, including inhibitors of the IL-7 pathway or pathways associated with self-renewal and 'stem cell-ness', such as those being developed for treating of leukemias and cancers. Indeed, by limiting immune activation and affecting long-lived infected $\mathrm{CD}^{+} \mathrm{T}$ cells by targeting IL-7-dependent proliferation and 
the self-renewal of memory $\mathrm{T}$ cells, in association with HAART, will pave the way for the eradication of virus in aviremic individuals. ${ }^{106}$

Other molecules, which are capable of activating latent provirus include agents such as the non-tumor-inducing phorbol ester prostratin. Prostratin inhibits HIV infection and viral spread at the entry/fusion step of viral life cycle. The lack of tumor promotion of prostratin coupled with its ability to upregulate latent HIV-1 provirus expression and inhibition of viral infection are important features that could be exploited as an effective therapy to eliminate latent reservoirs. ${ }^{201}$ Histone deacetylase inhibitors such as valproic acid ${ }^{202}$ and certain modulators of cellular microRNAs, ${ }^{202}$ can activate latent provirus. Unfortunately, to date, none of the strategies have translated clinically in effectively purging the latent virus from the reservoir sites. The caveat with these technologies is that robust viral activation can also lead to undesirable immune activation. Thus, further refinement is needed to their clinical translation.

\section{Shock to kill approach using histone deacetylases}

Savarino and colleagues have studied the so-called 'barrier of latency', which has been the main obstacle to eradicating HIV from the body. ${ }^{203}$ Cells harboring a quiescent virus are responsible for HIV persistence during therapy. They have found a new way that could drive out the stubborn virus from infected cells so that the body's immune system or drugs have a chance to kill them. ${ }^{203}$ A class of inhibitors called histone deacetylases, which keep HIV in its dormant state, only work at toxic doses. Histone deacetylase (HDAC) is a host mediator of gene repression, which inhibits HIV gene expression and virus production thereby contributing to quiescence of HIV within resting CD4 T cells. ${ }^{204} \mathrm{~A}$ recent proof of concept study by Lehrman and colleagues ${ }^{202}$ showed that combination therapy with an HDAC inhibitor and intensified HAART safely accelerates the clearance of HIV from resting $\mathrm{CD}^{+} \mathrm{T}$ cells in vivo, suggesting a new and practical approach to eliminate HIV infection in this persistent reservoir. However, extensive patient-based studies are required to support this proof of concept study. Moreover, the beneficial effects of this drug are visible on HIV only when used in toxic concentrations.

Furthermore, they have also shown ${ }^{203}$ that adding a second drug called buthionine sulfoximine along with HDAC 'awakens' the infected cells at lower doses, while leaving the virus-free cells intact. It appears that at non-toxic quantities, class I HDAC inhibitors were able to induce the 'awakening' of a portion of cells within a latently infected cell population.
The researchers then repeated the experiment adding a drug inducing oxidative stress, buthionine sulfoximine (BSO). The results showed that BSO was able to recruit cells non-responsive to the HDAC inhibitors into a responding cell population. Clearly evident was that the infected cells' 'awakening' was followed by cell death, whereas the non-infected cells were spared by the drug combination.

\section{Enhanced killing approach}

Methods for enhanced killing of recently activated HIVinfected cells are also being investigated. One such example is immunotoxins, which are composed of a targeting domain derived from a monoclonal antibody linked to a toxic moiety. For this purpose, the immunotoxin specifically targeting cells expressing the HIV envelope protein have been used to deplete both latently infected $\mathrm{T}$ cells $\mathrm{s}^{205}$ and infected macrophages ${ }^{206}$ after upregulation of HIV gene expression with stimulants. 'Activation-elimination' strategies such as this may therefore accelerate clearance of HIV from its various cellular reservoirs. Moreover, if this type of approach were used in conjunction with post-exposure vaccination or genetically modified stem cell immune reconstitution strategies, it might prove even more effective in decreasing or eliminating latent and persistent viral reservoirs. While many of the approaches outlined above are still at the developmental stages and are not without limitations, it is hoped that some of these nascent strategies will rapidly advance to the point that they can provide benefits to patients.

\section{Gene-based induction therapy targeting latent reservoirs of HIV-I}

One approach to eradication of the latent reservoir is induction therapy, whereby latently infected cells are activated to initiate viral replication. Herpes virus saimiri protein StpC has been shown to enhance HIV-1 replication in MOLT4 cells, suggesting it may be a useful tool for induction therapy. ${ }^{207}$ An induction vector containing StpC and a suicide gene such as Herpes simplex virus thymidine kinase (TK) may be utilized as a novel treatment targeting latently infected cells. Turner and colleagues ${ }^{207}$ have shown that the transfection with a suicide vector based on StpC and TK increased HIV-1 replication compared to cells transfected with a vector containing TK alone. The addition of ganciclovir resulted in reduced HIV-1 p24 levels in the cells transfected with the StpC-TK vector. This study provides proof of concept that gene induction therapy using suicide vectors encoding StpC to target cells latently infected with 
HIV-1 may offer a new approach to treating latent HIV-1. These studies will lead to a better understanding of viral latency and its disruption; and will assist development of improved techniques towards targeting latent reservoirs.

\section{Genetic therapies against HIV}

In the absence or presence of chemotherapy, gene therapy offers some hope of combating HIV infection via sustained interference with HIV replication in vivo. It is believed that the emergence of viral resistance and the establishment of reservoirs seen during HAART are the biggest impediments to successful HAART. These may possibly be addressed by gene therapies that use combinations of genetic agents for inhibiting both viral and host gene targets. Several of these strategies have already been or are being tested in planned clinical trials. These include, RNA-based agents (ribozymes, antisense, RNA aptamers and small interfering RNA (RNAi), protein-based agents, (mutant HIV Rev protein M10, fusion inhibitors, zinc-finger nucleases, dominant-negative proteins, intrabodies, intrakines). Recent advances in T-cell-based strategies include: gene-modified HIV-resistant T cells; lentiviral gene delivery; $\mathrm{CD}^{+} \mathrm{T}$ cells; T bodies; and engineered T-cell receptors. HIV-resistant hematopoietic stem cells have the potential to protect all cell types susceptible to HIV infection.

Overall, of several gene therapies tested so far none have fared successfully. Viral escape is a major problem, which will and has confounded every gene therapy approach tried to date. Although cellular targets are far less prone to mutational escape, the long-term side effects are unclear. Another major confounding factor is the specific targeting of the anti-HIV gene to have maximal effect against HIV-1 coupled with minimal cellular toxicity.

\section{Conclusions}

Even though eradication of HIV in the infected host appears to be extremely complex and challenging with the currently prescribed antiretroviral drugs, researchers should not abandon the goal of finding ways to challenge HIV, and developing strategies for either the long-term containment of HIV replication and prevention of immune dysfunction during HIV infection, or flushing out HIV from the reservoir sites in vivo. Although the latter has proven extremely difficult, it will need a coordinated effort and innovative thinking from scientists and clinicians alike.

\section{Disclosures}

The authors declare no conflict of interest relevant to this research.

\section{References}

1. Barre-Sinoussi F, Chermann JC, Rey F, et al. Isolation of a T-lymphotropic retrovirus from a patient at risk for acquired immune deficiency syndrome (AIDS). Science. 1983;220:868-871.

2. UNAIDS. 2008 Report on the global AIDS epidemic. 2008. Available from: http://www.unaids.org/en/KnowledgeCentre/HIVData/GlobalReport/2008/. Accessed May 10, 2010.

3. UNAIDS. 2007 AIDS epidemic update. Available from: http://www. unaids.org/en/KnowledgeCentre/HIVData/EpiUpdate/EpiUpdArchive/2007/default.asp. Accessed May 10, 2010.

4. Hirschel B, Opravil M. The year in review: antiretroviral treatment. Aids. 1999;13 Suppl A:S177-S187.

5. Wong JK, Hezareh M, Gunthard HF, et al. Recovery of replication-competent HIV despite prolonged suppression of plasma viremia. Science. 1997;278:1291-1295.

6. Blankson JN, Persaud D, Siliciano RF. The challenge of viral reservoirs in HIV-1 infection. Annu Rev Med. 2002;53:557-593.

7. Worgall S, Connor R, Kaner RJ, et al. Expression and use of human immunodeficiency virus type 1 coreceptors by human alveolar macrophages. J Virol. 1999;73:5865-5874.

8. Potter SJ, Dwyer DE, Saksena NK. Differential cellular distribution of HIV-1 drug resistance in vivo: evidence for infection of $\mathrm{CD}^{+} \mathrm{T}$ cells during HAART. Virology. 2003;305:339-352.

9. Chun TW, Finzi D, Margolick J, Chadwick K, Schwartz D, Siliciano RF. In vivo fate of HIV-1-infected T cells: quantitative analysis of the transition to stable latency. Nat Med. 1995;1:1284-1290.

10. Clarke JR, Taylor IK, Fleming J, Nukuna A, Williamson JD, Mitchell DM. The epidemiology of HIV-1 infection of the lung in AIDS patients. Aids. 1993;7:555-560.

11. Di Stefano M, Sabri F, Leitner T, et al. Reverse transcriptase sequence of paired isolates of cerebrospinal fluid and blood from patients infected with human immunodeficiency virus type 1 during zidovudine treatment. J Clin Microbiol. 1995;33:352-355.

12. Poss M, Martin HL, Kreiss JK, et al. Diversity in virus populations from genital secretions and peripheral blood from women recently infected with human immunodeficiency virus type 1. J Virol. 1995;69:8118-8122.

13. Chun TW, Carruth L, Finzi D, et al. Quantification of latent tissue reservoirs and total body viral load in HIV-1 infection. Nature. 1997;387:183-188.

14. Delwart EL, Mullins JI, Gupta P, et al. Human immunodeficiency virus type 1 populations in blood and semen. J Virol. 1998;72:617-623.

15. van't Wout AB, Ran LJ, Kuiken CL, Kootstra NA, Pals ST, Schuitemaker H. Analysis of the temporal relationship between human immunodeficiency virus type 1 quasispecies in sequential blood samples and various organs obtained at autopsy. J Virol. 1998;72:488-496.

16. Saksena NK, Potter SJ. Reservoirs of HIV-1 in vivo: implications for antiretroviral therapy. AIDS Rev. 2003;5:3-18.

17. Tenner-Racz K, Racz P, Schmidt H, et al. Immunohistochemical, electron microscopic and in situ hybridization evidence for the involvement of lymphatics in the spread of HIV-1. Aids. 1988;2: 299-309.

18. Pantaleo G, Graziosi C, Butini L, et al. Lymphoid organs function as major reservoirs for human immunodeficiency virus. Proc Natl Acad Sci U S A. 1991;88:9838-9842.

19. Fox CH, Tenner-Racz K, Racz P, Firpo A, Pizzo PA, Fauci AS. Lymphoid germinal centers are reservoirs of human immunodeficiency virus type 1 RNA. J Infect Dis. 1991;164:1051-1057.

20. Haase AT, Henry K, Zupancic M, et al. Quantitative image analysis of HIV-1 infection in lymphoid tissue. Science. 1996;274:985-989.

21. Cavert W, Notermans DW, Staskus K, et al. Kinetics of response in lymphoid tissues to antiretroviral therapy of HIV-1 infection. Science. 1997;276:960-964.

22. Cheynier R, Henrichwark S, Hadida F, et al. HIV and T cell expansion in splenic white pulps is accompanied by infiltration of HIV-specific cytotoxic T lymphocytes. Cell. 1994;78:373-387.

23. Frost SD, Gunthard HF, Wong JK, Havlir D, Richman DD, Leigh Brown AJ. Evidence for positive selection driving the evolution of HIV-1 env under potent antiviral therapy. Virology. 2001;284:250-258. 
24. Wong JK, Gunthard HF, Havlir DV, et al. Reduction of HIV-1 in blood and lymph nodes following potent antiretroviral therapy and the virologic correlates of treatment failure. Proc Natl Acad Sci U S A. 1997;94:12574-12579.

25. Lafeuillade A, Poggi C, Tamalet C, Profizi N. Human immunodeficiency virus type 1 dynamics in different lymphoid tissue compartments. J Infect Dis. 1997; 176:804-806.

26. Tamalet C, Lafeuillade A, Fantini J, Poggi C, Yahi N. Quantification of HIV-1 viral load in lymphoid and blood cells: assessment during four-drug combination therapy. AIDS. 1997;11:895-901.

27. Gunthard HF, Wong JK, Ignacio CC, et al. Human immunodeficiency virus replication and genotypic resistance in blood and lymph nodes after a year of potent antiretroviral therapy. J Virol. 1998;72:2422-2428.

28. Brandtzaeg P. Overview of the mucosal immune system. Curr Top Microbiol Immunol. 1989;146:13-25.

29. Poles MA, Elliott J, Taing P, Anton PA, Chen IS. A preponderance of CCR5(+) CXCR4(+) mononuclear cells enhances gastrointestinal mucosal susceptibility to human immunodeficiency virus type 1 infection. J Virol. 2001;75:8390-8399.

30. Clayton F, Snow G, Reka S, Kotler DP. Selective depletion of rectal lamina propria rather than lymphoid aggregate CD4 lymphocytes in HIV infection. Clin Exp Immunol. 1997;107:288-292.

31. Lim SG, Condez A, Lee CA, Johnson MA, Elia C, Poulter LW. Loss of mucosal CD4 lymphocytes is an early feature of HIV infection. Clin Exp Immunol. 1993;92:448-454.

32. Schneider T, Jahn HU, Schmidt W, Riecken EO, Zeitz M, Ullrich R. Loss of CD4 T lymphocytes in patients infected with human immunodeficiency virus type 1 is more pronounced in the duodenal mucosa than in the peripheral blood. Berlin Diarrhea/Wasting Syndrome Study Group. Gut. 1995;37:524-529.

33. Mellors JW, Rinaldo CRJr, Gupta P, White RM, Todd JA, Kingsley LA. Prognosis in HIV-1 infection predicted by the quantity of virus in plasma. Science. 1996;272:1167-1170.

34. Quinn TC. Viral load, circumcision and heterosexual transmission. Hopkins HIV Rep. 2000;12:1, 5, 11.

35. Fleming DT, Wasserheit JN. From epidemiological synergy to public health policy and practice: the contribution of other sexually transmitted diseases to sexual transmission of HIV infection. Sex Transm Infect. 1999; 75:3-17.

36. Amerongen HM, Weltzin R, Farnet CM, Michetti P, Haseltine WA, Neutra MR. Transepithelial transport of HIV-1 by intestinal M cells: a mechanism for transmission of AIDS. J Acquir Immune Defic Syndr. 1991;4:760-765.

37. Fotopoulos G, Harari A, Michetti P, Trono D, Pantaleo G, Kraehenbuhl JP. Transepithelial transport of HIV-1 by M cells is receptor-mediated. Proc Natl Acad Sci U S A. 2002;99:9410-9414.

38. Frankel SS, Wenig BM, Burke AP, et al. Replication of HIV-1 in dendritic cell-derived syncytia at the mucosal surface of the adenoid. Science. 1996;272:115-117.

39. Meng G, Sellers MT, Mosteller-Barnum M, Rogers TS, Shaw GM, Smith PD. Lamina propria lymphocytes, not macrophages, express CCR5 and CXCR4 and are the likely target cell for human immunodeficiency virus type 1 in the intestinal mucosa. J Infect Dis. 2000;182:785-791.

40. Cerf-Bensussan N, Guy-Grand D. Intestinal intraepithelial lymphocytes. Gastroenterol Clin North Am. 1991;20:549-576.

41. Lee SH, Starkey PM, Gordon S. Quantitative analysis of total macrophage content in adult mouse tissues. Immunochemical studies with monoclonal antibody F4/80. J Exp Med. 1985;161:475-489.

42. Ullrich R, Schieferdecker HL, Ziegler K, Riecken EO, Zeitz M. gamma delta T cells in the human intestine express surface markers of activation and are preferentially located in the epithelium. Cell Immunol. 1990;128:619-627.

43. Schnittman SM, Lane HC, Greenhouse J, Justement JS, Baseler M, Fauci AS. Preferential infection of $\mathrm{CD}^{+}$memory $\mathrm{T}$ cells by human immunodeficiency virus type 1: evidence for a role in the selective T-cell functional defects observed in infected individuals. Proc Natl Acad Sci U S A. 1990;87:6058-6062.
44. Anton PA, Elliott J, Poles MA, et al. Enhanced levels of functional HIV-1 co-receptors on human mucosal T cells demonstrated using intestinal biopsy tissue. AIDS. 2000;14:1761-1765.

45. Smith PD, Meng G, Shaw GM, Li L. Infection of gastrointestinal tract macrophages by HIV-1. J Leukoc Biol. 1997;62:72-77.

46. Smith PD, Smythies LE, Mosteller-Barnum M, et al. Intestinal macrophages lack CD14 and CD89 and consequently are down-regulated for LPS- and IgA-mediated activities. J Immunol. 2001;167:2651-2656.

47. Li S, Juarez J, Alali M, et al. Persistent CCR5 utilization and enhanced macrophage tropism by primary blood human immunodeficiency virus type 1 isolates from advanced stages of disease and comparison to tissue-derived isolates. J Virol. 1999;73:9741-9755.

48. Smith PD, Fox CH, Masur H, Winter HS, Alling DW. Quantitative analysis of mononuclear cells expressing human immunodeficiency virus type 1 RNA in esophageal mucosa. J Exp Med. 1994;1800:1541-1546.

49. Smith PD, Meng G, Sellers MT, Rogers TS, Shaw GM. Biological parameters of HIV-1 infection in primary intestinal lymphocytes and macrophages. J Leukoc Biol. 2000;68:360-365.

50. Resnick L, Berger JR, Shapshak P, Tourtellotte WW. Early penetration of the blood-brain-barrier by HIV. Neurology. 1988;38:9-14.

51. Nath A. Human immunodeficiency virus (HIV) proteins in neuropathogenesis of HIV dementia. J Infect Dis. 2002;186 Suppl 2:S193-198.

52. Navia BA, Jordan BD, Price RW. The AIDS dementia complex: I. Clinical features. Ann Neurol. 1986;19:517-524.

53. Kure K, Weidenheim KM, Lyman WD, Dickson DW. Morphology and distribution of HIV-1 gp41-positive microglia in subacute AIDS encephalitis. Pattern of involvement resembling a multisystem degeneration. Acta Neuropathol. 1990;80:393-400.

54. Kaul M, Garden GA, Lipton SA. Pathways to neuronal injury and apoptosis in HIV-associated dementia. Nature. 2001;410:988-994.

55. Lawrence DM, Major EO. HIV-1 and the brain: connections between HIV-1-associated dementia, neuropathology and neuroimmunology. Microbes Infect. 2002;4:301-308.

56. Wang Z, Trillo-Pazos G, Kim SY, et al. Effects of human immunode ficiency virus type 1 on astrocyte gene expression and function: potential role in neuropathogenesis. J Neurovirol. 2004;10 Suppl 1:25-32.

57. Petito CK. Human immunodeficiency virus type 1 compartmentalization in the central nervous system. J Neurovirol. 2004;10 Suppl 1:21-24.

58. Gartner S. HIV infection and dementia. Science. 2000;287:602-604.

59. Liu Y, Tang XP, McArthur JC, Scott J, Gartner S. Analysis of human immunodeficiency virus type 1 gp160 sequences from a patient with HIV dementia: evidence for monocyte trafficking into brain. J Neurovirol. 2000;6 Suppl 1:S70-81.

60. Nottet HS, Gendelman HE. Unraveling the neuroimmune mechanisms for the HIV-1-associated cognitive/motor complex. Immunol Today. 1995;16:441-448.

61. Falangola MF, Petito CK. Choroid plexus infection in cerebral toxoplasmosis in AIDS patients. Neurology. 1993;43:2035-2040.

62. Falangola MF, Castro-Filho BG, Petito CK. Immune complex deposition in the choroid plexus of patients with acquired immunodeficiency syndrome. Ann Neurol. 1994;36:437-440.

63. Falangola MF, Hanly A, Galvao-Castro B, Petito CK. HIV infection of human choroid plexus: a possible mechanism of viral entry into the CNS. J Neuropathol Exp Neurol. 1995;54:497-503.

64. Hanly A, Petito CK. HLA-DR-positive dendritic cells of the normal human choroid plexus: a potential reservoir of HIV in the central nervous system. Hum Pathol. 1998;29:88-93.

65. Chen H, Wood C, Petito CK. Comparisons of HIV-1 viral sequences in brain, choroid plexus and spleen: potential role of choroid plexus in the pathogenesis of HIV encephalitis. J Neurovirol. 2000;6:498-506.

66. Petito CK, Chen H, Mastri AR, Torres-Munoz J, Roberts B, Wood C. HIV infection of choroid plexus in AIDS and asymptomatic HIVinfected patients suggests that the choroid plexus may be a reservoir of productive infection. J Neurovirol. 1999;5:670-677.

67. Overbaugh J, Anderson RJ, Ndinya-Achola JO, Kreiss JK. Distinct but related human immunodeficiency virus type 1 variant populations in genital secretions and blood. AIDS Res Hum Retroviruses. 1996;12:107-115. 
68. Zhang H, Dornadula G, Beumont M, et al. Human immunodeficiency virus type 1 in the semen of men receiving highly active antiretroviral therapy. N Engl J Med. 1998;339:1803-1809.

69. Schlegel P CS. Physiology of male reproduction: the testes, epididymis, and ductus deferens. Campbell's Urology. 1998;7:1254-1286.

70. Coombs RW, Reichelderfer PS, Landay AL. Recent observations on HIV type-1 infection in the genital tract of men and women. AIDS 2003; 17:455-480.

71. Quayle AJ, Xu C, Mayer KH, Anderson DJ. T lymphocytes and macrophages, but not motile spermatozoa, are a significant source of human immunodeficiency virus in semen. J Infect Dis. 1997;176: 960-968.

72. Gupta P, Mellors J, Kingsley L, et al. High viral load in semen of human immunodeficiency virus type 1-infected men at all stages of disease and its reduction by therapy with protease and nonnucleoside reverse transcriptase inhibitors. J Virol. 1997;71:6271-6275.

73. Liuzzi G, Chirianni A, Clementi M, et al. Analysis of HIV-1 load in blood, semen and saliva: evidence for different viral compartments in a cross-sectional and longitudinal study. AIDS. 1996;10:F51-56.

74. da Silva M, Shevchuk MM, Cronin WJ, et al. Detection of HIV-related protein in testes and prostates of patients with AIDS. Am J Clin Pathol. 1990;93:196-201.

75. Pudney J, Anderson D. Orchitis and human immunodeficiency virus type 1 infected cells in reproductive tissues from men with the acquired immune deficiency syndrome. Am J Pathol. 1991;139: $149-160$.

76. Nuovo GJ, Becker J, Simsir A, Margiotta M, Khalife G, Shevchuk M. HIV-1 nucleic acids localize to the spermatogonia and their progeny. A study by polymerase chain reaction in situ hybridization. Am J Pathol. 1994;144:1142-1148.

77. Muciaccia B, Filippini A, Ziparo E, Colelli F, Baroni CD, Stefanini M. Testicular germ cells of HIV-seropositive asymptomatic men are infected by the virus. J Reprod Immunol. 1998;41:81-93.

78. Shevchuk MM, Nuovo GJ, Khalife G. HIV in testis: quantitative histology and HIV localization in germ cells. J Reprod Immunol. 1998;41:69-79.

79. Howell AL, Edkins RD, Rier SE, et al. Human immunodeficiency virus type 1 infection of cells and tissues from the upper and lower human female reproductive tract. J Virol. 1997;71:3498-3506.

80. Belec L. The HIV-1 reservoir in the female genital tract. Afr Health. 1999;21:19-21.

81. Kovacs A, Wasserman SS, Burns D, et al. Determinants of HIV-1 shedding in the genital tract of women. Lancet. 2001;358:1593-1601.

82. Jeffrey AA, Israel-Biet D, Andrieu JM, Even P, Venet A. HIV isolation from pulmonary cells derived from bronchoalveolar lavage. Clin Exp Immunol. 1991;84:488-492.

83. Lewin SR, Kirihara J, Sonza S, Irving L, Mills J, Crowe SM. HIV-1 DNA and mRNA concentrations are similar in peripheral blood monocytes and alveolar macrophages in HIV-1-infected individuals. Aids. 1998;12:719-727.

84. Chayt KJ, Harper ME, Marselle LM, et al. Detection of HTLV-III RNA in lungs of patients with AIDS and pulmonary involvement. JAMA. 1986;256:2356-2359.

85. Twigg HL, Soliman DM, Day RB, et al. Lymphocytic alveolitis, bronchoalveolar lavage viral load, and outcome in human immunodeficiency virus infection. Am J Respir Crit Care Med. 1999;159: 1439-1444.

86. White NC, Israel-Biet D, Coker RJ, Mitchell DM, Weber JN, Clarke JR. Different resistance mutations can be detected simultaneously in the blood and the lung oRf HIV-1 infected individuals on antiretroviral therapy. J Med Virol. 2004;72:352-357.

87. Bruggeman LA, Ross MD, Tanji N, et al. Renal epithelium is a previously unrecognized site of HIV-1 infection. J Am Soc Nephrol. 2000;11:2079-2087.

88. Marras D, Bruggeman LA, Gao F, et al. Replication and compartmentalization of HIV-1 in kidney epithelium of patients with HIV-associated nephropathy. Nat Med. 2002;8:522-526.
89. Klatzmann D, Barre-Sinoussi F, Nugeyre MT, et al. Selective tropism of lymphadenopathy associated virus (LAV) for helper-inducer T lymphocytes. Science. 1984;225:59-63.

90. Ho DD, Rota TR, Hirsch MS. Infection of monocyte/macrophages by human T lymphotropic virus type III. J Clin Invest. 1986;77: 1712-1715.

91. Feng Y, Broder CC, Kennedy PE, Berger EA. HIV-1 entry cofactor: functional cDNA cloning of a seven-transmembrane, $G$ protein-coupled receptor. Science. 1996;272:872-877.

92. Kwa D, Vingerhoed J, Boeser-Nunnink B, Broersen S, Schuitemaker H Cytopathic effects of non-syncytium-inducing and syncytium-inducing human immunodeficiency virus type 1 variants on different CD4(+) -Tcell subsets are determined only by coreceptor expression. $J$ Virol. 2001;75:10455-10459.

93. Mo H, Monard S, Pollack H, et al. Expression patterns of the HIV type 1 coreceptors CCR 5 and CXCR4 on CD4 ${ }^{+} \mathrm{T}$ cells and monocytes from cord and adult blood. AIDS Res Hum Retroviruses. 1998;14: 607-617.

94. Zack JA, Arrigo SJ, Chen IS. Control of expression and cell tropism of human immunodeficiency virus type 1. Adv Virus Res. 1990;38: 125-146.

95. Psallidopoulos MC, Schnittman SM, Thompson LM 3rd, et al. Integrated proviral human immunodeficiency virus type 1 is present in $\mathrm{CD} 4^{+}$peripheral blood lymphocytes in healthy seropositive individuals J Virol. 1989;63:4626-4631.

96. Pantaleo G, Graziosi C, Demarest JF, et al. HIV infection is active and progressive in lymphoid tissue during the clinically latent stage of disease. Nature. 1993;362:355-358.

97. Hufert FT, van Lunzen J, Janossy G, et al. Germinal centre CD4 ${ }^{+} \mathrm{T}$ cells are an important site of HIV replication in vivo. AIDS. 1997;11: 849-857.

98. van der Ende ME, Schutten M, Raschdorff B, et al. CD4 T cells remain the major source of HIV-1 during end stage disease. AIDS. 1999;13:1015-1019.

99. Veazey RS, DeMaria M, Chalifoux LV, et al. Gastrointestinal tract as a major site of $\mathrm{CD}^{+} \mathrm{T}$ cell depletion and viral replication in SIV infection. Science. 1998;280:427-431.

100. Calabro ML, Zanotto C, Calderazzo F, et al. HIV-1 infection of the thymus: evidence for a cytopathic and thymotropic viral variant in vivo. AIDS Res Hum Retroviruses. 1995;11:11-19.

101. Kitchen SG, Zack JA. CXCR4 expression during lymphopoiesis: implications for human immunodeficiency virus type 1 infection of the thymus. J Virol. 1997;71:6928-6934.

102. Ho DD, Neumann AU, Perelson AS, Chen W, Leonard JM, Markowitz M Rapid turnover of plasma virions and CD4 lymphocytes in HIV-1 infection. Nature. 1995;373:123-126.

103. Wei X, Ghosh SK, Taylor ME, et al. Viral dynamics in human immunodeficiency virus type 1 infection. Nature. 1995;373:117-122.

104. Pitcher CJ, Quittner C, Peterson DM, et al. HIV-1-specific CD4 $\mathrm{T}$ cells are detectable in most individuals with active HIV-1 infection, but decline with prolonged viral suppression. Nat Med. 1999;5: 518-525.

105. Philpott SM. HIV-1 coreceptor usage, transmission, and disease progression. Curr HIV Res. 2003;1:217-227.

106. Chomont N, El-Far M, Ancuta P, et al. HIV reservoir size and persistence are driven by $\mathrm{T}$ cell survival and homeostatic proliferation. Nat Med. 2009;15:893-900.

107. Brennan TP, Woods JO, Sedaghat AR, Siliciano JD, Siliciano RF, Wilke CO. Analysis of human immunodeficiency virus type 1 viremia and provirus in resting $\mathrm{CD}^{+} \mathrm{T}$ cells reveals a novel source of residual viremia in patients on antiretroviral therapy. J Virol. 2009;83:8470-8481.

108. Mercure L, Phaneuf D, Wainberg MA. Detection of unintegrated human immunodeficiency virus type 1 DNA in persistently infected $\mathrm{CD}^{+}$cells. J Gen Virol. 1993;74 (Pt 10):2077-2083.

109. Semenzato G, Agostini C, Ometto L, et al. CD8 ${ }^{+}$T lymphocytes in the lung of acquired immunodeficiency syndrome patients harbor human immunodeficiency virus type 1. Blood. 1995;85:2308-2314. 
110. Brooks DG, Kitchen SG, Kitchen CM, Scripture-Adams DD, Zack JA. Generation of HIV latency during thymopoiesis. Nat Med. 2001;7:459-464.

111. McBreen S, Imlach S, Shirafuji T, et al. Infection of the $\mathrm{CD} 45 \mathrm{RA}^{+}$(naive) subset of peripheral CD8 ${ }^{+}$lymphocytes by human immunodeficiency virus type 1 in vivo. J Virol. 2001;75:4091-4102.

112. Flamand L, Crowley RW, Lusso P, Colombini-Hatch S, Margolis DM, Gallo RC. Activation of $\mathrm{CD}^{+} \mathrm{T}$ lymphocytes through the T cell receptor turns on CD4 gene expression: implications for HIV pathogenesis. Proc Natl Acad Sci US A. 1998;95:3111-3116.

113. Imlach S, McBreen S, Shirafuji T, Leen C, Bell JE, Simmonds P. Activated peripheral CD8 lymphocytes express CD4 in vivo and are targets for infection by human immunodeficiency virus type 1 . JVirol. 2001;75:11555-11564.

114. Kitchen SG, Jones NR, LaForge S, et al. CD4 on CD8(+) T cells directly enhances effector function and is a target for HIV infection. Proc Natl Acad Sci U S A. 2004;101:8727-8732.

115. Saha K, Zhang J, Gupta A, Dave R, Yimen M, Zerhouni B. Isolation of primary HIV-1 that target $\mathrm{CD}^{+} \mathrm{T}$ lymphocytes using $\mathrm{CD} 8$ as a receptor. Nat Med. 2001;7:65-72.

116. Livingstone WJ, Moore M, Innes D, Bell JE, Simmonds P. Frequent infection of peripheral blood CD8-positive T-lymphocytes with HIV-1. Edinburgh Heterosexual Transmission Study Group. Lancet. 1996;348:649-654.

117. Herbein G, Mahlknecht U, Batliwalla F, et al. Apoptosis of CD8 ${ }^{+}$ T cells is mediated by macrophages through interaction of HIV gp 120 with chemokine receptor CXCR4. Nature. 1998;395:189-194.

118. Kalams SA, Walker BD. The critical need for CD4 help in maintaining effective cytotoxic T lymphocyte responses. J Exp Med. 1998;188:2199-2204.

119. Roederer M, Dubs JG, Anderson MT, Raju PA, Herzenberg LA, Herzenberg LA. CD8 naive T cell counts decrease progressively in HIV-infected adults. J Clin Invest. 1995;95:2061-2066.

120. Bohler T, Walcher J, Holzl-Wenig G, et al. Early effects of antiretroviral combination therapy on activation, apoptosis and regeneration of $\mathrm{T}$ cells in HIV-1-infected children and adolescents. AIDS. 1999;13: 779-789.

121. Collman R, Godfrey B, Cutilli J, et al. Macrophage-tropic strains of human immunodeficiency virus type 1 utilize the CD4 receptor. J Virol. 1990;64:4468-4476.

122. Orenstein JM, Fox C, Wahl SM. Macrophages as a source of HIV during opportunistic infections. Science. 1997;276:1857-1861.

123. Wahl SM OJ, Smith PD. Macrophage function in HIV infection. Immunology of HIV Infection. New York, NY: New York Plenum; 1996:303-336.

124. Crowe SM, Mills J, Kirihara J, Boothman J, Marshall JA, McGrath MS. Full-length recombinant CD4 and recombinant gp120 inhibit fusion between HIV infected macrophages and uninfected CD4expressing T-lymphoblastoid cells. AIDS Res Hum Retroviruses. 1990;6:1031-1037.

125. Meltzer MS, Nakamura M, Hansen BD, Turpin JA, Kalter DC, Gendelman HE. Macrophages as susceptible targets for HIV infection, persistent viral reservoirs in tissue, and key immunoregulatory cells that control levels of virus replication and extent of disease. AIDS Res Hum Retroviruses. 1990;6:967-971.

126. Deng H, Liu R, Ellmeier W, et al. Identification of a major co-receptor for primary isolates of HIV-1. Nature. 1996;381:661-666.

127. Doms RW. Chemokine receptors and HIV entry. AIDS. 2001;15 Suppl 1:S34-35.

128. YiY, Rana S, Turner JD, Gaddis N, Collman RG. CXCR-4 is expressed by primary macrophages and supports CCR5-independent infection by dual-tropic but not T-tropic isolates of human immunodeficiency virus type 1. J Virol. 1998;72:772-777.

129. Chowdhury IH, Bentsman G, Choe W, Potash MJ, Volsky DJ. The macrophage response to HIV-1: Intracellular control of X4 virus replication accompanied by activation of chemokine and cytokine synthesis. J Neurovirol. 2002;8:599-610.
130. Vadiveloo PK. Macrophages - proliferation, activation, and cell cycle proteins. J Leukoc Biol. 1999;66:579-582.

131. Garaci E, Caroleo MC, Aloe L, et al. Nerve growth factor is an autocrine factor essential for the survival of macrophages infected with HIV. Proc Natl Acad Sci U S A. 1999;96:14013-14018.

132. Aquaro S, Bagnarelli $P$, Guenci $T$, et al. Long-term survival and virus production in human primary macrophages infected by human immunodeficiency virus. J Med Virol. 2002;68:479-488.

133. Kohler JJ, Tuttle DL, Coberley CR, Sleasman JW, Goodenow MM. Human immunodeficiency virus type 1 (HIV-1) induces activation of multiple STATs in CD4 ${ }^{+}$cells of lymphocyte or monocyte/macrophage lineages. J Leukoc Biol. 2003;73:407-416.

134. Pelchen-Matthews A, da Silva RP, Bijlmakers MJ, Signoret N, Gordon S, Marsh M. Lack of p56lck expression correlates with CD4 endocytosis in primary lymphoid and myeloid cells. Eur J Immunol. 1998;28:3639-3647.

135. O’Brien WA, Namazi A, Kalhor H, Mao SH, Zack JA, Chen IS. Kinetics of human immunodeficiency virus type 1 reverse transcription in blood mononuclear phagocytes are slowed by limitations of nucleotide precursors. J Virol. 1994;68:1258-1263.

136. Heinzinger NK, Bukinsky MI, Haggerty SA, et al. The Vpr protein of human immunodeficiency virus type 1 influences nuclear localization of viral nucleic acids in nondividing host cells. Proc Natl Acad Sci US A. 1994;91:7311-7315.

137. Tuttle DL, Anders CB, Aquino-De Jesus MJ, et al. Increased replication of non-syncytium-inducing HIV type 1 isolates in monocyte-derived macrophages is linked to advanced disease in infected children. AIDS Res Hum Retroviruses. 2002;18:353-362.

138. Perelson AS, Essunger P, Cao Y, et al. Decay characteristics of HIV-1-infected compartments during combination therapy. Nature. 1997;387:188-191.

139. Embretson J, Zupancic M, Ribas JL, et al. Massive covert infection of helper T lymphocytes and macrophages by HIV during the incubation period of AIDS. Nature. 1993;362:359-362.

140. McElrath MJ, Steinman RM, Cohn ZA. Latent HIV-1 infection in enriched populations of blood monocytes and T cells from seropositive patients. J Clin Invest. 1991;87:27-30.

141. Innocenti P, Ottmann M, Morand P, Leclercq P, Seigneurin JM. HIV-1 in blood monocytes: frequency of detection of proviral DNA using PCR and comparison with the total CD4 count. AIDS Res Hum Retroviruses. 1992;8:261-268

142. Patterson BK, Till M, Otto P, et al. Detection of HIV-1 DNA and messenger RNA in individual cells by PCR-driven in situ hybridization and flow cytometry. Science. 1993;260:976-979.

143. Sonza S, Maerz A, Deacon N, Meanger J, Mills J, Crowe S. Human immunodeficiency virus type 1 replication is blocked prior to reverse transcription and integration in freshly isolated peripheral blood monocytes. J Virol. 1996;70:3863-3869.

144. Lambotte O, TaoufikY, de Goer MG, Wallon C, Goujard C, Delfraissy JF. Detection of infectious HIV in circulating monocytes from patients on prolonged highly active antiretroviral therapy. J Acquir Immune Defic Syndr. 2000;23:114-119.

145. Zhu T, Muthui D, Holte S, et al. Evidence for human immunodeficiency virus type 1 replication in vivo in CD14(+) monocytes and its potential role as a source of virus in patients on highly active antiretroviral therapy. J Virol. 2002;76:707-716.

146. Sonza S, Mutimer HP, Oelrichs R, et al. Monocytes harbour replicationcompetent, non-latent HIV-1 in patients on highly active antiretroviral therapy. AIDS. 2001;15:17-22.

147. Ziegler-Heitbrock HW, Ulevitch RJ. CD14: cell surface receptor and differentiation marker. Immunol Today. 1993;14:121-125.

148. Persidsky Y, Ghorpade A, Rasmussen J, et al. Microglial and astrocyte chemokines regulate monocyte migration through the blood-brain barrier in human immunodeficiency virus-1 encephalitis. Am J Pathol. 1999;155:1599-1611.

149. Katz SI, Tamaki K, Sachs DH. Epidermal Langerhans cells are derived from cells originating in bone marrow. Nature. 1979;282:324-326. 
150. Garrett WS, Chen LM, Kroschewski R, et al. Developmental control of endocytosis in dendritic cells by Cdc42. Cell. 2000;102:325-334.

151. Tschachler E, Groh V, Popovic M, et al. Epidermal Langerhans cells - a target for HTLV-III/LAV infection. J Invest Dermatol. 1987;88:233-237.

152. Geijtenbeek TB, Kwon DS, Torensma R, et al. DC-SIGN, a dendritic cell-specific HIV-1-binding protein that enhances trans-infection of T cells. Cell. 2000;100:587-597.

153. Turville SG, Cameron PU, Handley A, et al. Diversity of receptors binding HIV on dendritic cell subsets. Nat Immunol. 2002;3:975-983.

154. Kwon DS, Gregorio G, Bitton N, Hendrickson WA, Littman DR. DC-SIGN-mediated internalization of HIV is required for transenhancement of T cell infection. Immunity. 2002;16:135-144.

155. Cameron PU, Freudenthal PS, Barker JM, Gezelter S, Inaba K, Steinman RM. Dendritic cells exposed to human immunodeficiency virus type- 1 transmit a vigorous cytopathic infection to $\mathrm{CD} 4^{+} \mathrm{T}$ cells. Science. 1992;257:383-387.

156. Lore K, Sonnerborg A, Brostrom C, et al. Accumulation of DC-SIGN+CD40+ dendritic cells with reduced CD80 and CD86 expression in lymphoid tissue during acute HIV-1 infection. AIDS 2002; 16:683-692.

157. Zhang L, Ramratnam B, Tenner-Racz K, et al. Quantifying residual HIV-1 replication in patients receiving combination antiretroviral therapy. N Engl J Med. 1999;340:1605-1613.

158. Frankel SS, Tenner-Racz K, Racz P, et al. Active replication of HIV-1 at the lymphoepithelial surface of the tonsil. Am J Pathol. 1997;151:89-96.

159. Koopman G, Pals ST. Cellular interactions in the germinal center: role of adhesion receptors and significance for the pathogenesis of AIDS and malignant lymphoma. Immunol Rev. 1992;126:21-45.

160. Jakubik JJ, Saifuddin M, Takefman DM, Spear GT. Immune complexes containing human immunodeficiency virus type 1 primary isolates bind to lymphoid tissue B lymphocytes and are infectious for $\mathrm{T}$ lymphocytes. J Virol. 2000;74:552-555.

161. Moir S, Malaspina A, Li Y, et al. B cells of HIV-1-infected patients bind virions through CD21-complement interactions and transmit infectious virus to activated T cells. J Exp Med. 2000;192: 637-646.

162. Malaspina A, Moir S, Nickle DC, et al. Human immunodeficiency virus type 1 bound to B cells: relationship to virus replicating in $\mathrm{CD}^{+} \mathrm{T}$ cells and circulating in plasma. $J$ Virol. 2002;76: $8855-8863$

163. Scott-Algara D, Paul P. NK cells and HIV infection: lessons from other viruses. Curr Mol Med. 2002;2:757-768.

164. Cooper MA, Fehniger TA, Caligiuri MA. The biology of human natural killer-cell subsets. Trends Immunol. 2001;22:633-640.

165. Valentin A, Rosati M, Patenaude DJ, et al. Persistent HIV-1 infection of natural killer cells in patients receiving highly active antiretroviral therapy. Proc Natl Acad Sci U S A. 2002;99:7015-7020.

166. Lucia MB, Froio N, Tacconelli E, et al. CD16+CD56+CD8+ natural killer (NK) cells are decreased during HIV infection. Eur J Histochem. 1997;41 Suppl 2:197-198.

167. Chang J, Jozwiak R, Wang B, et al. Unique HIV type 1 V3 region sequences derived from six different regions of brain: region-specific evolution within host-determined quasispecies. AIDS Res Hum Retroviruses. 1998;14:25-30.

168. Saksena NK, Wang B, Ge YC, et al. Region-specific changes, gene duplications, and random deletions in the nef gene from HIV type 1-infected brain tissues and blood of a demented patient. AIDS Res Hum Retroviruses. 1997;13:111-116.

169. Tashima KT, Flanigan TP, Kurpewski J, Melanson SM, Skolnik PR. Discordant Human Immunodeficiency Virus Type 1 drug resistance mutations, including K103N, observed in cerebrospinal fluid and plasma. Clin Infect Dis. 2002;35:82-83.

170. Kim AE, Dintaman JM, Waddell DS, Silverman JA. Saquinavir, an HIV protease inhibitor, is transported by P-glycoprotein. J Pharmacol Exp Ther. 1998;286:1439-1445.
171. Kim RB, Fromm MF, Wandel C, et al. The drug transporter P-glycoprotein limits oral absorption and brain entry of HIV-1 protease inhibitors. J Clin Invest. 1998;101:289-294.

172. Gottesman MM, Pastan I. Biochemistry of multidrug resistance mediated by the multidrug transporter. Annu Rev Biochem. 1993;62:385-427.

173. Choo EF, Leake B, Wandel C, et al. Pharmacological inhibition of P-glycoprotein transport enhances the distribution of HIV-1 protease inhibitors into brain and testes. Drug Metab Dispos. 2000;28: 655-660.

174. Smit TK, Brew BJ, Tourtellotte W, Morgello S, Gelman BB, Saksena NK. Independent evolution of human immunodeficiency virus (HIV) drug resistance mutations in diverse areas of the brain in HIV-infected patients, with and without dementia, on antiretroviral treatment. J Virol. 2004;78:10133-10148.

175. Brew BJ, Rosenblum M, Cronin K, Price RW. AIDS dementia complex and HIV-1 brain infection: clinical-virological correlations. Ann Neurol. 1995;38:563-570.

176. Dejucq N, Jegou B. Viruses in the mammalian male genital tract and their effects on the reproductive system. Microbiol Mol Biol Rev. 2001;65:208-231.

177. Cohen MS, Hoffman IF, Royce RA, et al. Reduction of concentration of HIV-1 in semen after treatment of urethritis: implications for prevention of sexual transmission of HIV-1. AIDSCAP Malawi Research Group. Lancet. 1997;349:1868-1873.

178. Bart J, Groen HJ, van der Graaf WT, et al. An oncological view on the blood-testis barrier. Lancet Oncol. 2002;3:357-363.

179. Byrn RA, Zhang D, Eyre R, McGowan K, Kiessling AA. HIV-1 in semen: an isolated virus reservoir. Lancet. 1997;350:1141.

180. Ghosn J, Viard JP, Katlama C, et al. Evidence of genotypic resistance diversity of archived and circulating viral strains in blood and semen of pre-treated HIV-infected men. AIDS. 2004;18:447-457.

181. Kemal KS, Foley B, Burger H, et al. HIV-1 in genital tract and plasma of women: compartmentalization of viral sequences, coreceptor usage, and glycosylation. Proc Natl Acad Sci U SA. 2003;100:12972-12977.

182. Poss M, Rodrigo AG, Gosink JJ, et al. Evolution of envelope sequences from the genital tract and peripheral blood of women infected with clade A human immunodeficiency virus type 1. JVirol. 1998;72:8240-8251.

183. Zhang L, Rowe L, He T, et al. Compartmentalization of surface envelope glycoprotein of human immunodeficiency virus type 1 during acute and chronic infection. J Virol. 2002;76:9465-9473.

184. Barnett SW, Barboza A, Wilcox CM, Forsmark CE, Levy JA. Characterization of human immunodeficiency virus type 1 strains recovered from the bowel of infected individuals. Virology. 1991;182:802-809.

185. al-Mulla W, Church D, Gill MJ. Phenotypic variations and switches in HIV isolated from the blood and the gastrointestinal tissues of patients with HIV-1 infection. HIV/GI Research Study Group. J Med Virol. 1997;52:31-34.

186. van der Hoek L, Sol CJ, Maas J, Lukashov VV, Kuiken CL, Goudsmit J. Genetic differences between human immunodeficiency virus type 1 subpopulations in faeces and serum. J Gen Virol. 1998;79 (Pt 2):259-267.

187. Poles MA, Elliott J, Vingerhoets J, et al. Despite high concordance, distinct mutational and phenotypic drug resistance profiles in human immunodeficiency virus type 1 RNA are observed in gastrointestinal mucosal biopsy specimens and peripheral blood mononuclear cells compared with plasma. J Infect Dis. 2001;183:143-148.

188. Simmonds P, Zhang LQ, McOmish F, Balfe P, Ludlam CA, Brown AJ. Discontinuous sequence change of human immunodeficiency virus (HIV) type 1 env sequences in plasma viral and lymphocyte-associated proviral populations in vivo: implications for models of HIV pathogenesis. J Virol. 1991;65:6266-6276.

189. Wang YM, Dyer WB, Workman C, Wang B, Sullivan JS, Saksena NK Molecular evidence for drug-induced compartmentalization of HIV-1 quasispecies in a patient with periodic changes to HAART. AIDS. 2000;14:2265-2272. 
190. Romano L, Venturi G, Catucci M, De Milito A, Valensin PE, Zazzi M. Evaluation of cell-free and cell-associated peripheral blood human immunodeficiency virus type 1 RNA response to antiretroviral therapy. J Infect Dis. 1999;179:361-366.

191. Chun TW, Stuyver L, Mizell SB, et al. Presence of an inducible HIV-1 latent reservoir during highly active antiretroviral therapy. Proc Natl Acad Sci U S A. 1997;94:13193-13197.

192. Finzi D, Hermankova M, Pierson T, et al. Identification of a reservoir for HIV-1 in patients on highly active antiretroviral therapy. Science. 1997;278:1295-1300.

193. Pierson T, Hoffman TL, Blankson J, et al. Characterization of chemokine receptor utilization of viruses in the latent reservoir for human immunodeficiency virus type 1. J Virol. 2000;74:7824-7833.

194. Gunthard HF, Frost SD, Leigh-Brown AJ, et al. Evolution of envelope sequences of human immunodeficiency virus type 1 in cellular reservoirs in the setting of potent antiviral therapy. J Virol. 1999;73:9404-9412.

195. Aquaro S, Calio R, Balestra E, et al. Clinical implications of HIV dynamics and drug resistance in macrophages. J Biol Regul Homeost Agents. 1998;12:23-27.

196. Venturi G, Romano L, Carli T, et al. Divergent distribution of HIV-1 drug-resistant variants on and off antiretroviral therapy. Antivir Ther. 2002; 7:245-250.

197. Kepler TB, Perelson AS. Drug concentration heterogeneity facilitates the evolution of drug resistance. Proc Natl Acad Sci USA. 1998;95:11514-11519.

198. Turriziani O, Schuetz JD, Focher F, et al. Impaired 2',3'-dideoxy-3'thiacytidine accumulation in T-lymphoblastoid cells as a mechanism of acquired resistance independent of multidrug resistant protein 4 with a possible role for ATP-binding cassette C11. Biochem J. 2002;368: $325-332$.
199. Saksena NK, Haddad DN. Viral reservoirs an impediment to HAART: new strategies to eliminate HIV-1. Curr Drug Targets Infect Disord. 2003;3:179-206.

200. Lucia MB, Rutella S, Golotta C, Leone G, Cauda R. Differential induction of P-glycoprotein and MRP by rifamycins in T lymphocytes from HIV-1/tuberculosis co-infected patients. AIDS. 2002;16: 1563-1565.

201. Kulkosky J, Culnan DM, Roman J, et al. Prostratin: activation of latent HIV-1 expression suggests a potential inductive adjuvant therapy for HAART. Blood. 2001;98:3006-3015.

202. Lehrman G, Hogue IB, Palmer S, et al. Depletion of latent HIV-1 infection in vivo: a proof-of-concept study. Lancet. 2005;366: 549-555.

203. Savarino A, Mai A, Norelli S, et al. "Shock and kill" effects of class I-selective histone deacetylase inhibitors in combination with the glutathione synthesis inhibitor buthionine sulfoximine in cell line models for HIV-1 quiescence. Retrovirology. 2009;6:52.

204. Ylisastigui L, Archin NM, Lehrman G, Bosch RJ, Margolis DM. Coaxing HIV-1 from resting CD4 T cells: histone deacetylase inhibition allows latent viral expression. AIDS. 2004;18:1101-1108.

205. Brooks DG, Hamer DH, Arlen PA, et al. Molecular characterization, reactivation, and depletion of latent HIV. Immunity. 2003;19: 413-423.

206. Marsden MD, Xu J, Hamer D, Zack JA. Short communication: Activating stimuli enhance immunotoxin-mediated killing of HIV-infected macrophages. AIDS Res Hum Retroviruses. 2008;24: 1399-1404.

207. Turner LS, Tsygankov AY, Henderson EE. StpC-based gene therapy targeting latent reservoirs of HIV-1. Antiviral Res. 2006;72: 233-241.
HIV/AIDS - Research and Palliative Care

\section{Publish your work in this journal}

HIV/AIDS - Research and Palliative Care is an international, peerreviewed open-access journal focusing on advances in research in HIV, its clinical progression and management options including antiviral treatment, palliative care and public healthcare policies to control viral spread. The journal welcomes original research, basic science,

\section{Dovepress}

clinical \& epidemiological studies, reviews \& evaluations, expert opinion \& commentary, case reports \& extended reports. The manuscript management system is completely online and includes a very quick and fair peer-review system. Visit http://www.dovepress.com/ testimonials.php to read real quotes from published authors. 